\title{
Kohti kriittistä editiota. Musiikkifilologinen analyysi Leevi Madetojan ensimmäisen sinfonian käsikirjoituslähteistä
}

\begin{abstract}
JOHDANTO
Leevi Madetojan (1887-1947) ensimmäisen sinfonian F-duuri, opus 29 (1916) käsikirjoituslähteisiin lukeutuu kaksi täydellistä partituuria vuosilta 1916 ja 1943 sekä yksi erillinen sinfonian toisen osan partituuri, todennäköisesti vuodelta 1916. Kaikki kolme partituurikäsikirjoitusta ovat autografisia, siis säveltäjän käsialaa, ja niitä säilytetään Kansalliskirjastossa. ${ }^{1}$ Lisäksi käsikirjoituslähteisiin kuuluu käsin kopioituja orkesteriääniä, joita säilytetään Kansalliskirjastossa, Helsingin kaupunginarkistossa ja musiikkikustantamo Fennica Gehrmanilla Helsingissä. Musiikki-Fazerin² vuonna 1984 painattamassa partituurissa on lukuisia virheitä, ja se on osoittautunut eklektiseksi hybridiksi vuosien 1916 ja 1943 käsikirjoituksista. Samat virheet toistuvat Fennica Gehrmanin vuonna 2002 tietokoneella puhtaaksikirjoittamissa orkesteriäänissä. Nykypäivänä tämänlaista lähteiden sekoittamista pidetään kyseenalaisena etenkin, kun lähteenä käytettyjä käsikirjoituksia erottaa toisistaan reilu neljännesvuosisata.

Keväällä 2020 ehdotin Fennica Gehrmanille uuden kriittisen edition julkaisemista tästä teoksesta, ja kustantamon kiinnostuttua projektista aloitin välittömästi työni käsikirjoituslähteiden vertailemisen parissa. Kriittisen edition toimittamiseen liittyviin valintoihin vaikuttaa viime kädessä se, minkälaiseen lopputulokseen pyritään. Otetaanko huomioon säveltäjän viimeisimmätkin muokkaukset, jolloin johtotähtenä on "säveltäjän viimeinen tahto" (Fassung letzter Hand), vai pyritäänkö lähelle sitä muotoa, jossa teos on ensi kertaa esitetty? ${ }^{3}$ Kummassakin tapauksessa käsikirjoituslähteet täytyy luokitella, ajoittaa ja asettaa lähdeketjuun. Lähde voi olla funktioltaan esimerkiksi luonnos, alkuperäinen käsikirjoitus, esittämistä varten tehty lisäkopio tai kustantamoa varten tehty puhtaaksikirjoitus. Genealogista menetelmää

1 Käsikirjoitukset ovat luettavissa artikkelin liitteissä. Olen esitellyt sinfonian kolme partituurikäsikirjoitusta ensimmäisen kerran taiteellisen tohtorintutkintoni kirjallisessa työssä (Mäkilä 2018) ja myöhemmin kompilaatioartikkelissani (Mäkilä 2020). Kiitän lämpimästi Madetoja-rahastoa ja Kauppaneuvos Otto A. Malmin lahjoitusrahastoa Leevi Madetojan orkesterimusiikin tutkimukseen vastaanottamastani tuesta. Liite 1: https:// trio.journal.fi/article/view/110033/64676. Liite 2: https://trio.journal.fi/article/view/110033/64677

2 Jatkossa Fazer. Yritys on tunnettu myös nimillä Oy Fazerin musiikkikauppa ja Fazer Musiikki Oy.

3 Tämä ongelma on tuttu Brucknerin, Mahlerin ja Hindemithin teoksista (Grier 1996, 70).
\end{abstract}


käyttämällä ja biografiseen informaatioon tukeutuen voidaan rakentaa lähteiden sukupuu eli stemma (Grier 1996, 62-64).

Madetojan orkesterimusiikista ei ole aiemmin tehty musiikkifilologista tutkimusta. ${ }^{4}$ Madetojan oopperoita tutkinut Kauko Karjalainen tyytyy väitöskirjassaan Leevi Madetojan oopperat Pohjalaisia ja Juha toteamaan, että tuntemattoman kopistin kopioimaa partituuria tutkiessaan hän huomasi, että "joissakin esityksissä on Pohjalaisten eräitä kohtauksia lyhennelty, paikoin jopa radikaalisti” ja että Juhan partituurissa "näkyivät esitysten yhteydessä tehdyt muutokset (hypyt ja lyhennykset) selvästi autografisesta orkesteripartituurista" (Karjalainen 1991, 44).

Madetojan mieskuoroteosten käsikirjoituksia pro gradu -työssään tutkinut Tuomas Niemelä vahvistaa Madetoja-biografi Erkki Salmenhaaran käsityksen Madetojan tavasta kirjoittaa sävellyksensä ensin lyijykynällä ja puhtaaksikirjoittaa ne musteella suoraan lyijykynäjäljen päälle (Niemelä 2017,16-17). Niemelä myös huomioi säveltäjän tavan tehdä teoksiinsa pieniä muutoksia uusintapainoksia varten (ibid., 24).

Suomalaisen orkesterimusiikin musiikkifilologisen tutkimuksen uranuurtaja on ollut Sibelius-tutkija Kari Kilpeläinen, jonka ohella Sibeliuksen orkesterikäsikirjoituksia ovat tutkineet muiden muassa Risto Väisänen, Timo Virtanen ja Tuija Wicklund. Jean Sibeliuksen kokonaistuotannon kriittisen edition julkaisuprojektissa (JSW) on käsitelty hyvin samankaltaisia kysymyksiä kuin mihin Madetojan tuotantoa tutkiva törmää. Selkeimmät erot tulevat esiin lähdemateriaalissa, sillä Madetojan orkesterimusiikista valtaosa on edelleen painamatta, kun taas Sibeliuksen orkesteriteoksista suurin osa julkaistiin laadukkaina painotuotteina säveltäjän elinaikana. ${ }^{5}$

Analyysini ammentaa musiikkifilologian teoreettisesta viitekehyksestä, etenkin James Grierin teoksesta The Critical Editing of Music: History, Method, and Practice (1996), joka on yksi tieteenalan harvoja perusteoksia. ${ }^{6}$ Metodina olen käyttänyt tekstikriittistä analyysia. Olen tutkinut sekä alkuperäisiä käsikirjoituksia että partituurien korkearesoluutioisia skannauksia ja orkesterin äänilehtien valokuvajäljennöksiä. ${ }^{7}$

Käsikirjoituksien ajoittamiseen voi Kilpeläisen $(1992,12)$ mukaan käyttää neljänlaisia seikkoja, joita ovat (1) käytetyt nuottipaperit, (2) nuotti- ja kirjoituskäsiala,

4 Veijo Murtomäen (1999) mukaan musiikkifilologia on musiikkitieteen osa-alue, joka koskee musiikin kirjoitettuja tekstejä eli notaatioita. Koska julkaistu nuottiteksti usein sisältää poikkeavuuksia, muutoksia ja suoranaisia virheitä alkuperäiseen nuottilähteeseen verrattuna, tulisi notaatioiden tutkimuksen edeltää muuta musiikintutkimusta. Musiikkifilologiassa pyritään käyttämään autenttisimpia alkuperäislähteitä, jotka kuvaillaan ja tulkitaan tekstikritiikin avulla.

5 Madetojan ja Sibeliuksen lähdetilanne rinnastuu mielenkiintoisella tavalla Mozartin ja Beethovenin lähdetilanteeseen. Mozart näki vain muutaman teoksensa painettuna, kun taas Beethoven sävelsi varsinkin myöhemmät teoksensa nimenomaan julkaisua silmälläpitäen (Grier 1996, 39).

6 Toinen alan hyvin tunnettu perusteos on Georg Federin Musikphilologie (1987).

7 Vain osa tutkittavista yksityiskohdista voidaan selvittää jäljennösten perusteella, joten alkuperäisten käsikirjoitusten tutkiminen on ehdottoman välttämätöntä (Grier 1996, 55). 
(3) kynänjäljet sekä (4) muut ajoitusta auttavat asiat, joista tärkeimpiä ovat käsikirjoituksiin tehdyt merkinnät. Madetojan kynänjäljistä olen voinut tehdä vain pintapuolisia havaintoja, koska pidemmälle menevien johtopäätöksien tekemiseen tarvittaisiin laajempi vertailuaineisto. Sama koskee nuottipapereita, sillä muiden kuin Breitkopf \& Härtelin painattaman paperin osalta on olemassa hyvin vähän aiempaa tutkimusta. Madetojan nuottikäsialan muuttuminen vuosien 1916 ja 1943 välillä on puolestaan helposti todettavissa jo tämän artikkelin pohjana olevan aineiston perusteella. ${ }^{8}$

Ensimmäisessä luvussa kuvaan lyhyesti Madetojan ensimmäisen sinfonian sävellys- ja esityshistorian sekä sen julkaisuhistorian 2000-luvulle saakka. Sitä seuraa tiivistelmä kaikista tunnetuista käsikirjoituslähteistä. Kolmannessa luvussa esittelen sinfonian tunnetut partituurikäsikirjoitukset, niiden ajoitukset ja sukulaisuussuhteet, minkä jälkeen esittelen sinfonian säilyneet käsin kirjoitetut orkesteriäänet, niiden ajoitukset ja sukulaisuuden partituurikäsikirjoituksiin. Lopuksi esittelen koko lähdemateriaaliin perustuvan lähdepuun ja osoitan myös, mihin 1980-luvulla painettu partituuri ja 2000-luvulla puhtaaksikirjoitetut orkesteriäänet siinä sijoittuvat. Artikkelin lopuksi pohdin, mikä käsikirjoituksista olisi sopivin uuden kriittisen edition päälähteeksi ja miten paljon painoarvoa muille lähteille tulisi antaa toimitustyössä.

\section{MAdETOJAN ENSIMMÄISEN SINFONIAN SÄVELLYS-, ESITYS- JA JULKAISUHISTORIA}

Leevi Madetoja kirjoitti ensimmäisen sinfoniansa lyhyissä jaksoissa vuosien 1914 ja 1916 välillä, ja se valmistui kantaesityksen alla helmikuun 1916 alussa. Alun perin suunnitellun suuren neliosaisen orkesteriteoksen sijaan sinfoniasta tuli kolmiosainen ja vain reilun kahdenkymmenen minuutin pituinen (Salmenhaara 1987, 139). Madetojan velvollisuudet Viipurin Musiikin Ystävien orkesterin johdossa veivät aikaa sävellystyöltä ja haittasivat säveltäjän keskittymistä. ${ }^{9}$ Säveltäjä johti esikoissinfoniansa kantaesityksen Helsingin yliopiston juhlasalissa Helsingin kaupunginorkesterin ${ }^{10}$ kanssa 10 . helmikuuta 1916 , ja teos sai hyvän vastaanoton aikansa lehdistössä (ibid., 148). ${ }^{11}$ Sinfonia sai uuden esityksen jo kolme päivää myöhemmin jälleen säveltäjän johdolla, ja seuraavan kerran se oli HKO:n ohjelmistossa vuotta myöhemmin 15.2.1917 Robert Kajanuksen johtamana (Helsingin kaupunginorkes-

8 Myös Tuomas Niemelä on kiinnittänyt huomiota nuottikäsialan muutoksiin toimittamassaan Leevi Madetojan mieskuorolaulujen kriittisessä editiossa (Madetoja 2020,196).

9 Madetoja toimi Viipurin Musiikin Ystävien orkesterin johtajana vuosina 1914-1916 (Kuula 2006,191-208).

10 Jatkossa HKO.

11 Ks. esim. Helsingin Sanomat 11.2.1916, Hufvudstadsbladet 11.2.1916, Uusi Suometar 11.2.1916. 
teri 2020). Seuraavan kerran säveltäjä näyttää itse johtaneen teoksen Helsingissä 12.4.1923. ${ }^{12}$ Viipurissa Madetoja esitti sinfonian tuoreeltaan kahdesti maaliskuussa 1916 Viipurin Musiikin Ystävien orkesterin kanssa (Kuula 2006, 205).

Fazer kustansi Madetojan ensimmäisen sinfonian vasta vuonna 1943, ja sinfoniaa ei tuolloin painatettu, vaan jakelussa olivat käsin kirjoitetut orkesteriäänet ja säveltäjän autografiset partituurit. Säveltäjän kustannussopimusta varten tekemä uusi partituurikopio poikkeaa monissa kohdin alkuperäisestä käsikirjoituksesta. Fazer painatti teoksen partituurin vasta vuoden 1984 helmikuussa, ja sen toimitusprosessi ei ole kaikilta osin selvillä. ${ }^{13}$ Fennica Gehrman, jolle Fazerin kustantamien teosten oikeudet olivat yrityskauppojen seurauksena siirtyneet, kirjoitutti painettuun partituuriin sopivat nykyaikaiset orkesteriäänet korvaamaan käsin kirjoitetut materiaalit vuonna 2002. ${ }^{14}$

Sinfonia levytettiin ensi kertaa 1980-luvulla, ja varhaisin tunnettu arkistoäänitekin on vasta vuodelta 1956 (Mäkilä 2018, 86). Äänitteet ovat siis kustannussopimuksen tekemisen jälkeiseltä ajalta. Kaikki teosta esittäneet orkesterit ovat vuoden 1943 jälkeen käyttäneet Fazerin (ja myöhemmin Fennica Gehrmanin) vuokramateriaaleja, pois lukien muutamat $\mathrm{HKO}: n$ esitykset, joissa käytössä on ollut orkesterin omistama alkuperäinen nuottimateriaali. Näin on kadonnut muistista se tosiasia, että sinfonian kantaesitysversio eroaa monin paikoin tuntemastamme versiosta. Käsikirjoituslähteitä tutkimalla selviää, että säveltäjä on tehnyt teokseen muutoksia useassa eri vaiheessa vuosien 1916 ja 1943 välillä.

\section{SiNFONIAN TUNNETUT KÄSIKIRJOITUSLÄHTEET}

Kun aloitin tohtoriopintoni Viron musiikki- ja teatteriakatemiassa vuonna 2012 ja valitsin tutkimuskohteekseni Leevi Madetojan sinfoniat, ei ensimmäisen sinfonian käsikirjoituksen olinpaikkaa tunnettu. Tiedustelujeni tuloksena Fennica Gehrmanin arkistosta Helsingistä kuitenkin löytyi kaksi käsin kirjoitettua partituuria, joista toinen osoittautui säveltäjän alkuperäiseksi käsikirjoitukseksi (A) toisen ollessa sä-

12 HKO:n esitystilastosta löytyvät tiedot myös seuraavista esityksistä: Georg Schnéevoigt 3.2.1939, Jussi Jalas 2.5.1947, Toivo Haapanen 8.12.1947 ja Paavo Rautio 6.3.1980 (Helsingin kaupunginorkesteri 2020).

13 Fennica Gehrmanin hallussa olevan Madetojan 1. sinfonian arkistokappaleen sisäkanteen on merkitty painosmäärä 350 kappaletta ja päiväys 23.2.1984, joka on joko painoksen lähtöpäivä kirjapainosta tai sen saapumispäivä Fazerille.

14 Vuonna 1993 Musiikki-Fazer ja sen kustannustoiminta myytiin amerikkalaiselle Time Warnerille. Warner teki vuonna 2002 sopimuksen ruotsalaisen Gehrmans Musikförlag Ab:n kanssa suomalaisen ja ruotsalaisen vakavan musiikin kustannusoikeuksien hallinnoinnista, ja 2007 Warner myi nämä oikeudet Gehrmanille. Suomen osalta oikeuksia hallinnoi 2002 perustettu Gehrmanin suomalainen tytäryhtiö Fennica Gehrman. (von Bonsdorff 2012, 270-275.) 
Taulukko 1. Leevi Madetojan ensimmäisen sinfonian käsikirjoituslähteet ${ }^{15}$

\begin{tabular}{|c|c|c|c|c|}
\hline A & Säveltäjän alkuperäinen käsikirjoitus & 1916 & Kansalliskirjasto & Ms.Mus.163 Madetoja 4/4 \\
\hline B & Säveltäjän käsikirjoituskopio & $\begin{array}{l}\text { Päiväämätön, [1943 perustuen } \\
\text { säveltäjän päiväkirjamerkintöihin] }\end{array}$ & Kansalliskirjasto & Ms.Mus.163 Madetoja 4/4 \\
\hline C & $\begin{array}{l}\text { Säveltäjän käsikirjoituskopio sinfonian } \\
\text { toisesta osasta Lento misterioso, }\end{array}$ & $\begin{array}{l}\text { Päiväämätön, [1916 perustuen } \\
\text { nuottipaperiin ja yhtäläisyyksiin } \\
\text { A:n kanssa] }\end{array}$ & Kansalliskirjasto & Ms.Mus.Mt1 \\
\hline$P A$ & $\begin{array}{l}\text { Helsingin kaupunginorkesterin } \\
\text { orkesteriäänet (PA-1) ja irralliset } \\
\text { partituuriin } A \text { kytkettävissä olevat } \\
\text { nuottilehdet }(P A-2)(1916) \text {, myöhemmin } \\
\text { materiaaliin lisätyt etupulttien } \\
\text { äänilehdet (PA-3) ja yksittäinen } \\
\text { kakkosviulun lisäkopio }(P A-4)\end{array}$ & $\begin{array}{l}\text { PA-1 \& PA-2: } 1916 \\
\text { PA-2: } 1916 \\
\text { PA-3: [192?] } \\
\text { PA-4: [192?] }\end{array}$ & $\begin{array}{l}\text { Helsingin } \\
\text { kaupunginarkisto; } \\
\text { Kansalliskirjasto }\end{array}$ & $\begin{array}{l}\text { Ue:94 nuottimateriaali 530; } \\
\text { Ms.Mus.Suomen Säveltäjät } 8\end{array}$ \\
\hline PB & Musiikki-Fazerin orkesteriäänet & [1943] & $\begin{array}{l}\text { Fennica Gehrman, } \\
\text { Helsinki }\end{array}$ & \\
\hline PC & $\begin{array}{l}\text { Sinfonian toisen osan Lento misterioso } \\
\text { orkesteriäänet }\end{array}$ & [1916] & Kansalliskirjasto & Ms.Mus.Suomen Säveltäjät 8 \\
\hline
\end{tabular}

veltäjän omakätinen myöhempi kopio (B). ${ }^{16}$ A:n todistaa alkuperäiseksi paitsi ensimmäisen osan (virheellinen) päiväys "Wiipuri 15/1 1915 [sic]. L.M.", myös toisessa osassa olevat punakynällä tehdyt merkinnät osan lyhentämiseksi. Säveltäjä on poistanut osasta kaksi jaksoa - fis-duurissa alkavan 25 tahdin pituisen episodin (harjoituskirjaimet $\mathrm{G}$ ja $\mathrm{H}$ ), sekä 33 tahdin pituisen pääteeman kertauksen (harjoituskirjaimet I ja K). B:ssä osa on jo lyhennetyssä muodossaan, ja myös säveltäjän nuottikäsiala on siinä pelkistetympää. ${ }^{17}$

Myöhempi partituurikopio (B) on ensi silmäyksellä ulkoasultaan huomattavasti siistimpi kuin korjauksien ja eri esittäjien merkintöjen täplittämä alkuperäiskäsikirjoitus. Varmastikin tästä syystä se on 1980-luvulla valittu Fazerin painetun laitoksen lähtökohdaksi. Lähempi tarkastelu kuitenkin paljastaa B:stä paljon pieniä virheitä ja epäloogisuuksia, joita Fazerin julkaiseman nuotin puhtaaksikirjoittaja on yrittänyt paikata ottamalla mukaan yksityiskohtia A:sta. Tästä on seurannut lähteiden sekoittuminen eli musiikkifilologian termein kontaminaatio.

15 Käsikirjoituslähteille on tapana antaa kriittisessä editiossa koodi tai lyhenne, mutta mitään yhtenäistä käytäntöä ei ole muodostunut. Jotkin kriittiset editiot nimeävät lähteet kronologisesti A, B, C, D; toiset taas käyttävät lyhenteenä säilytyspaikkaa (esim. KK = Kansalliskirjasto, HKA = Helsingin kaupunginarkisto) tai painettujen lähteiden kohdalla kustantajaa ( $\mathrm{BH}=$ Breitkopf \& Härtel jne.), kun taas jotkut käyttävät informatiivisia koodeja kuten $\mathrm{A}$ = autografinen partituuri, $\mathrm{Fc}$ = "fair copy", $\mathrm{pA}$ = autografiset orkesteriäänet ("parts"). Itse olen nimennyt autografiset käsikirjoitukset vuoden 2018 tohtorintutkielmassani A, B ja C niiden painoarvon mukaan: eli vuoden 1916 autografinen täydellinen partituuri on lähteistä tärkein, vuoden 1943 partituuri on seuraavaksi tärkein lähde sinfonian kriittisen edition kannalta, ja toisen osan kopio vuodelta 1916 on partituureista vähämerkityksisin (Mäkilä 2018,31-32). Samassa yhteydessä olen nimennyt vuonna 1984 painetun partituurin kirjainlyhenteellä F (Fazer). Orkesteriäänet taas olen liittänyt edellisiin ja käyttänyt kaikkien kanssa etuliitteenä kirjainta P (englannin kielestä "orchestra parts").

16 Molemmat partituurit on Fennica Gehrman lahjoittanut Kansalliskirjaston kokoelmiin vuonna 2015.

17 Toisin sanoen A on ainoa käsikirjoituslähteistä, joka on päivätty, lukuun ottamatta B:ssä olevia (osin harhaanjohtavia, ks. myöh.) esityspäivämääriä ja orkesterimuusikoiden äänilehtiin kirjaamia esityspäivämääriä. 
Kansalliskirjastossa on lisäksi kolmaskin Madetojan käsialaa oleva partituurikäsikirjoitus (C), joka sisältää ainoastaan sinfonian toisen osan "Lento misterioso". Siihen on merkitty samat lyhennykset kuin A-partituuriin, ja muutenkin nuottiteksti on joitakin dynamiikkamerkintöjä lukuun ottamatta lähes identtinen A:n kanssa. Kansalliskirjastossa säilytetään myös käsin kirjoitettuja toisen osan orkesteriääniä (PC). HKO:lle kuuluneet orkesteriäänet (PA), joista teos on kantaesitetty, on talletettu Helsingin kaupunginarkistoon. Fazer kirjoitutti uudet orkesteriäänet (PB) oletettavasti vuonna 1944, mutta kyseisiä äänilehtiä on säilynyt vain neljä kappaletta. Käsinkirjoitetuista orkesteriäänistä on haluttu luopua vuonna 2002, kun Fennica Gehrman korvasi ne vuoden 1984 painettua partituuria vastaavilla nykyaikaisilla orkesteriäänillä.

Olen myös käynyt läpi Madetojan kirjeenvaihtoa ja säilyneitä päiväkirjoja niiltä osin kuin ne liittyvät ensimmäisen sinfonian vaiheisiin. Teos mainitaan Madetojan kirjeessä Eero Kososelle ${ }^{18}$ 29.12.1932 ja Arvo Räikkösen ${ }^{19}$ kirjeessä Madetojalle 23.9.1933. Säveltäjä on myös kommentoinut sinfoniansa kustantamista ja puhtaaksikirjoittamista vuoden 1943 päiväkirjassaan. ${ }^{20}$

\section{Partituurikäsikirjoitusten kuvaus ja sijoittaminen LÄHDEKETJUUN}

Madetojan ensimmäisen sinfonian partituurikäsikirjoituksia on mahdollista analysoida tekstikriittisesti ja vertaamalla niitä biografisiin lähteisiin. Nostan niistä seuraavaksi esiin ajoituksen ja lähdeketjuun sijoittamisen kannalta tärkeimpiä yksityiskohtia ja joitakin muita seikkoja. ${ }^{21}$

Lähde A on Kansalliskirjastossa säilytettävä säveltäjän alkuperäinen, alkuvuodesta 1916 valmistunut käsikirjoitus, minkä toteaminen perustuu ensimmäisen osan virheelliseen päiväykseen, luonnostelun asteeseen, sukulaisuuteen partituurien B ja C kanssa ja biografisiin tietoihin. Osa partituuriin tehdyistä lyijykynämerkinnöistä liittyy vuoden 1943 partituurin kopioimiseen ja osa vuoden 1984 partituurin editointiprosessiin, mikä paikoin vaikeuttaa säveltäjän alkuperäisen tekstin selvittämistä. Jokainen teoksen kolmesta osasta on kirjoitettu omaan nuottivihkoonsa, ja vihkot on sidottu yhteen kirjaksi. Ensimmäisessä vihkossa on käytetty kolmea eri nuotti-

18 Eero Kosonen (1906-2002) oli tamperelainen pianisti ja kapellimestari, joka johti Tampereen orkesteria (vuodesta 1947 Tampereen kaupunginorkesteri) vuosina 1932-1969.

19 Arvo Räikkönen (1906-1978) oli Turussa ja Raumalla vaikuttanut kuoronjohtaja, säveltäjä ja musiikkipedagogi.

20 Kyseisessä Leevi Madetojan päiväkirjassa ei ole vuosilukua, mutta olen ajoittanut sen vihkosessa mainitun Naantalin 500-vuotisjuhlan perusteella vuoteen 1943. Päiväkirjasta tarkemmin ks. Mäkilä 2021.

21 Partituurikäsikirjoitukset ja käsin kirjoitetut orkesteriäänet tullaan kuvailemaan yksityiskohtaisesti kriittisen edition kommentaarissa. 


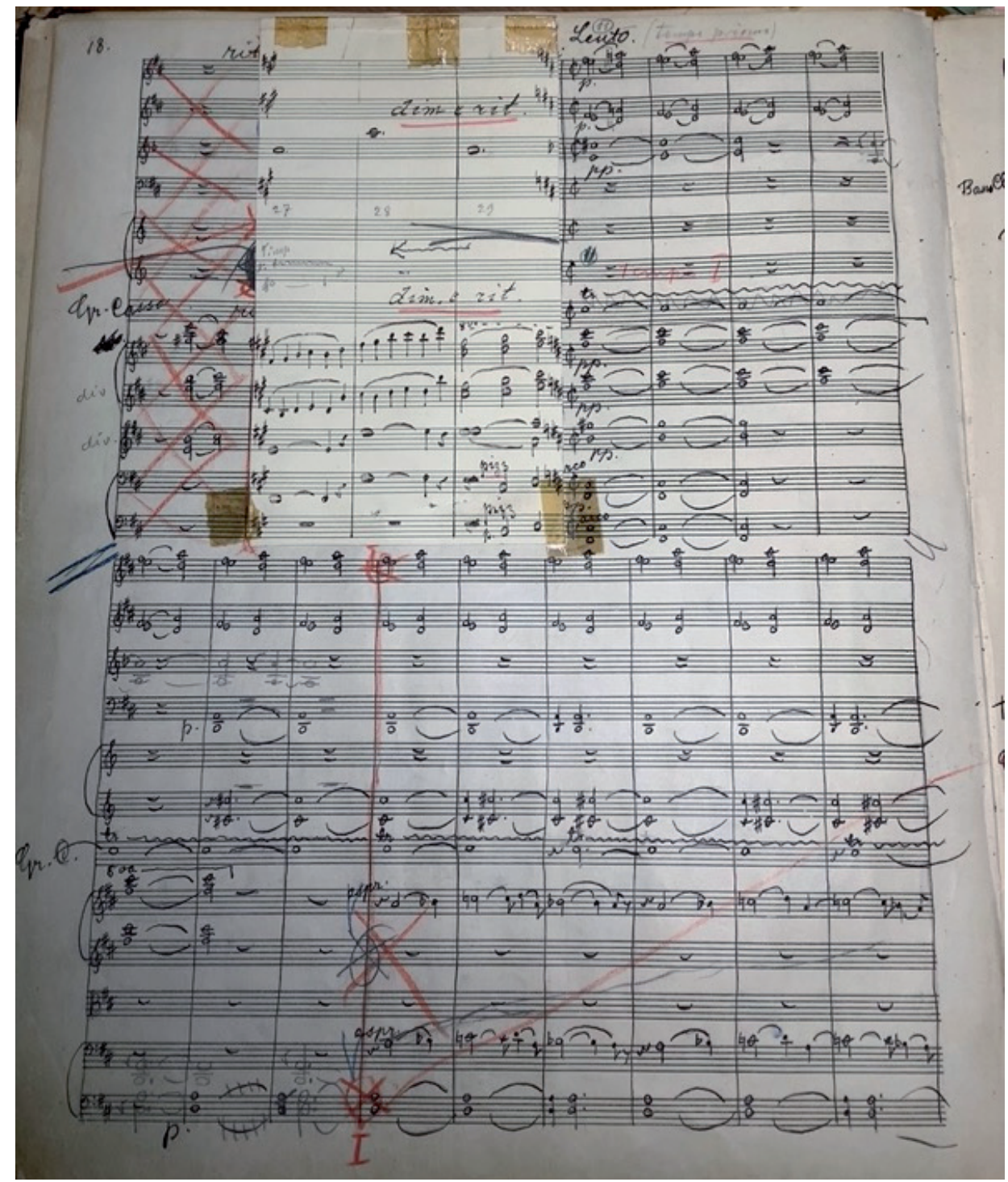

Kuva 1. Sinfonian toisen osan lyhentämistä varten tehty paikkaus partituurikäsikirjoituksessa A.

paperia: kahta Breitkopf \& Härtelin paperia ja yhtä tunnistamatonta. ${ }^{22}$ Toisessa ja

22 Osalla sivuista Breitkopf \& Härtelin liikemerkin perässä on koodi B\&H.Nr.11.A. ja sen alapuolella lisäluvut 6.12. Kari Kilpeläisen väitöskirjan liitteenä olevasta luettelosta käy ilmi, että Jean Sibelius on käyttänyt koodilla B\&H.Nr.11.A. varustettuja vesileimattomia nuottipapereita vuosien 1888 ja 1912 välillä, joskin yksittäinen konsepti on niinkin myöhäiseltä vuodelta kuin 1922 (Kilpeläinen 1992, 265-266). Kilpeläisen mukaan ensimmäinen lisäluku tarkoittaa kuukautta ja jälkimmäinen painovuotta (ibid., 14). Tässä yhteydessä se 
kolmannessa vihkossa on käytetty A. Apostolin nuottipaperia. ${ }^{23}$

Ensimmäisen osan viimeisen sivun päiväyksessä "Wiipuri 15/1 1915 [sic]. L.M.” herättää huomiota vuosi 1915 vuoden 1916 sijaan. Biografisen informaation perusteella sinfonian ensimmäinen osa valmistui Viipurissa tammikuussa 1916 (Salmenhaara 1987, 146). ${ }^{24}$ L. Onervan kanssa käydystä kirjeenvaihdosta selviää, että Madetoja on tammikuussa 1915 asunut myös Viipurissa, mutta työn alla oli tuolloin Sammon ryöstö-kantaatti (Makkonen \& Tuurna 2006, 172). ${ }^{25}$

Sinfonian toisen osan ensimmäisellä sivulla on HKO:n nuotiston sininen leima "No 530". ${ }^{26}$ Sivun 18 yläreunaan on kiinnitetty toisen osan lyhentämiseen liittyvä korjauslappu, johon on kirjoitettu kolme tahtia musiikkia (kuva 1). Korjauslapun nuottikäsiala vastaa Madetojan 1940-luvun käsialaa, jossa alaspäiset nuotinvarret kiinnittyvät standardinotaation mukaisesti nuotinpään vasempaan reunaan. Samalla sivulla on nähtävissä myös Madetojan 1910-luvun puolivälin tapa kiinnittää nuotin varsi lähes poikkeuksetta nuotinpään oikeaan reunaan. Kun korjauslappua vertaa B-partituuriin, näyttää käsiala hyvin samankaltaiselta. C-partituuriin on tehty sama leikkaus (ks. myöh.), mutta sen korjauslapussa puolinuottien varret kiinnittyvät nuotinpään oikeaan reunaan! Leikkauksen tarkka ajankohta on toistaiseksi arvoitus. Olisiko säveltäjä tehnyt leikkauksen aluksi ainoastaan omassa käytössään olevaan partituuriin C? Vai onko A-partituurin alkuperäinen korjauslappu mahdollisesti pudonnut, jolloin Madetoja olisi kirjoittanut uuden vuonna 1943 kopioidessaan partituuria Fazerille kustantamista varten, mikä selittäisi käsialojen eron?

Partituuri A on luonnosteltu Madetojalle tyypilliseen tapaan ensin lyijykynällä ja kirjoitettu sen jälkeen puhtaaksi mustalla musteella, minkä jälkeen lyijykynä on melko huolellisesti pyyhitty pois. Partituurissa on ensimmäiseltä sivulta lähtien pienellä tehtyjä lyijykynälisäyksiä, jotka nuottikäsialasta päätellen ovat säveltäjän itsensä myöhemmin tekemiä. Partituurissa on myös kapellimestarien merkintöjä. Punakynällä on merkitty sisääntuloja, alleviivattu esitysmerkintöjä, ympyröity nyansseja ja kirjoitettu instrumenttien lyhenteitä. Myös kaikki harjoituskirjaimet on kirjoitettu punaisella. Ne on varmastikin lisätty teokseen vasta sen valmistuttua, ja

tarkoittaisi sitä, että Madetojan A-partituurin ensimmäisessä vihkossa käyttämä nuottipaperi olisi painettu kesäkuussa 1912, mikä sopii hyvin yksiin sen tiedon kanssa, että säveltäjä on kirjoittanut sinfoniaansa vuosien 1915 ja 1916 aikana.

23 A. Apostols Musikhandel oli sotilaskapellimestari Alexei Apostolin (1866-1927) perustama musiikkikauppa.

24 Kirjeessään Onervalle 9.1.1916 Madetoja kertoo ensimmäisen osan valmistuvan "huomenna" (Makkonen \& Tuurna 2006, 234), ja 17.1.1916 Madetoja on kirjoittanut Robert Kajanukselle lähettäneensä tälle sinfonian ensimmäisen osan (Salmenhaara 1987,146). Tästä voi päätellä, että sinfonian ensimmäinen osa on valmistunut näiden kahden päivämäärän välillä. Vuosiluku on näin lähellä vuoden vaihtumista saattanut tulla virheellisesti vanhasta muistista, ja säveltäjä ei ole sitä myöhemmin katsonut aiheelliseksi korjata.

25 Madetojan puoliso L. Onerva (Hilja Onerva Lehtinen, 1882-1972) oli tunnettu runoilija, kirjailija ja suomentaja.

26 Sama leima löytyy HKO:n alkuperäisistä orkesterimateriaaleista, ks. myöh. 
ensimmäinen esittäjä on ollut säveltäjä itse. Tästä voi ehkä päätellä, että punainen kynänjälki on Madetojalta itseltään lähtöisin.

Sinisellä värillä on kirjoitettu lukuisia V-kirjaimen muotoisia merkkejä tärkeiden sisääntulojen kohdalle, ympyröity osa harjoituskirjaimista ja merkitty triangelin sisääntulo kolmiosymbolilla. Joitakin instrumenttien lyhenteitä on myös kirjoitettu sinisellä. Yhteneväisten merkintöjen vahvistaminen toisilla sivuilla sinisellä ja toisilla punaisella viittaa siihen, että kyseessä on kahden eri kapellimestarin merkinnät. ${ }^{27}$ Sinistä väriä on käytetty myös toisen osan pois leikatussa osuudessa, joten toista osaa ei ole soitettu pidemmässä versiossaan ainoastaan kantaesityksessä, vaan myös sen jälkeen ja myös jonkun muun kuin Madetojan toimesta.

Vihreällä värikynällä A-partituuriin on merkitty ainoastaan harjoitusnumerot. Vastaavia harjoitusnumeroita ei ole samalta ajalta olevassa partituurissa C, joten on syytä olettaa, että numerot on lisätty partituuriin vasta vuonna 1943. Sekä harjoituskirjaimien että harjoitusnumeroiden käyttö samaan aikaan on epätavallinen käytäntö, ja oletankin, että harjoitusnumeroiden käyttöönotto liittyy vuoden 1943 kustannussopimukseen. ${ }^{28}$ Fazerin käsin kirjoitetuissa orkesteriäänissä (PB) on ainoastaan harjoitusnumerot.

Partituurissa on myös kapellimestareiden lyijykynämerkintöjä, joista useimmat ovat numeroita, jotka ilmoittavat alkavan fraasin tahtien määrän. Suurikokoiset numerot toimivat muistutuksena johtamiskaavoista. Myös esitysmerkintöjä on suurennettu, ja kirjoitettu selväsanaisia muistutuksia, kuten "Hitaammin" ja piirretty nuoli taaksepäin. Toisen osan Doppio movimento -jaksossa on pasuunoiden kohdalle kirjoitettu "riktigt i stämmorna!"29 Lisäksi partituurissa on vuosien 1943 ja 1984 partituurien editointiprosesseihin liittyviä merkintöjä. Osa niistä on Madetojan käsialaa, osa taas tuntemattoman kopistin. ${ }^{30}$ Nämä merkinnät alkavat A:n sivulta 2, jossa ensimmäisen ja toisen tahdin välisen tahtiviivan yläpuolella on pieni numero 2 sen merkkinä, että tästä alkaa B-partituurin sivu 2. Pieni kolmonen on kirjoitettu harjoituskirjaimen A kohdalle B-partituurin kolmannen sivun alkamisen merkiksi ja niin edelleen. Kriittisen edition kannalta olisi tärkeää pystyä erottamaan toisistaan Madetojan lähellä sävellyksen syntyajankohtaa tekemät korjaukset, vuoden 1943 kustannussopimukseen ja partituurin puhtaaksikirjoittamiseen liittyvät merkinnät ja vuoden 1984 painetun partituurin editointiprosessiin liittyvät merkinnät. ${ }^{31}$ Siellä

27 Jokaisella kapellimestarilla on oma tapansa merkitä partituuri,joten toisen esittäjän merkinnöistä ei yleensä koeta olevan hyötyä. Tämän takia merkintöjä laina- ja vuokrapartituureissa usein kaksinnetaan.

28 Sekä harjoituskirjaimet että -numerot ovat jostain syystä päätyneet vuoden 1984 painettuun partituuriin.

29 Tämä viittaa siihen, että Madetoja orkestroi jakson uudelleen joskus vuosien 1916 ja 1943 välillä.

30 Vuoden 1984 partituurin toimitti mahdollisesti Madetojan sävellysoppilas Olavi Pesonen (1909-1993), joka tiettävästi oikoluki Madetojan kolmannen sinfonian vuonna 1987 painetun partituurin.

31 Käsikirjoituksesta olisi ehkä mahdollista tehdä stratigrafinen analyysi ja muodostaa matriisi, joka havainnollistaisi nuottitekstin eri aikakerrostumia. Stratigrafia eli kerrostumien tutkiminen kuuluu geologian ja arkeologian perusmetodeihin, mutta sitä on käytetty jonkin verran myös paleografiassa, etenkin keskiaikaisten 
täällä on säveltäjän käsialalla kirjoitettu "Obs!" ja vedetty viiva johonkin dissonoivaan säveleen. Lisäksi joidenkin tahtiviivojen yllä on pieniä rukseja, joiden merkitystä voi tässä vaiheessa vain arvailla.

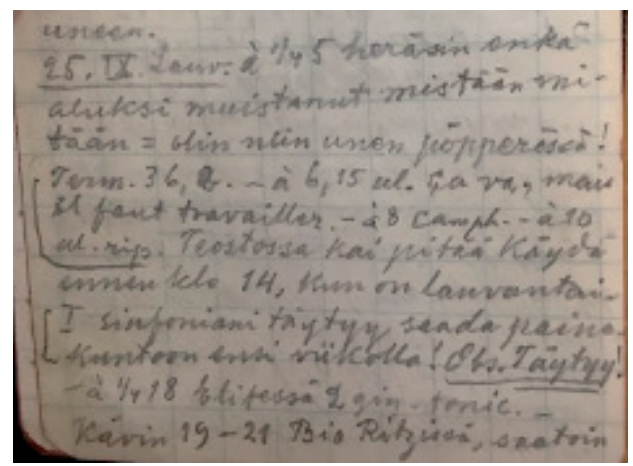

Kuva 2. Säveltäjän päiväkirjamerkintä 25.9.1943. "I sinfoniani täytyy saada painokuntoon ensi viikolla! Obs. Täytyy!"

Myös B-partituuri on lahjoitettu Kansalliskirjastoon vuonna 2015 Fennica Gehrmanin arkistosta, johon se puolestaan siirtyi Fazerin vuokranuotistosta. Partituuri itsessään on päiväämätön, mutta sen kirjoittamisajankohta voidaan säveltäjän päiväkirjamerkintöjen perusteella ajoittaa kustannussopimuksen vuoteen 1943 (kuva 2). Ennen päiväkirjamerkintöjen löytymistä B-partituurin ajoitusta hämärsi kuusi nimiölehden sisäsivulle kirjoitettua esityspäivämäärää (kuva 3). Päivämääristä kaksi on ajalta ennen partituurin kirjoittamista, vuosilta 1933 ja 1939, ja loput 1940-luvulta. Viimeinen päivämäärä sijoittuu joitakin viikkoja säveltäjän kuoleman jälkeen. Kaksi ensimmäistä merkintää on kuitenkin tehty jälkikäteen, vaikka syytä siihen voi vain arvailla. Ehkä muistiongelmista kärsinyt säveltäjä halusi dokumentoida viime vuosien esitykset partituurin yhteyteen, tai sitten merkinnät on tehnyt kustantaja.

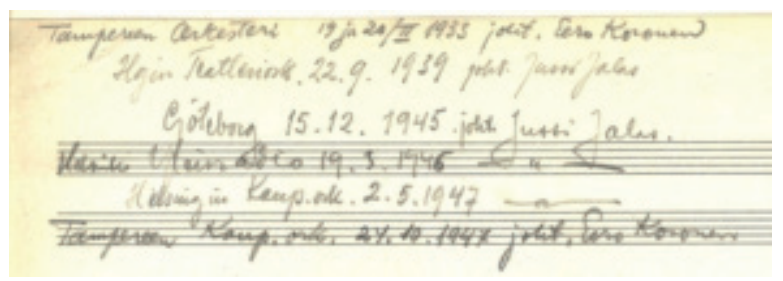

Kuva 3. B-partituurin sisäsivulle kirjoitettuja esityspäivämääriä.

käsikirjoituksien tulkinnassa. Stratigrafinen lähestymistapa puoltaisi paikkaansa myös musiikkikäsikirjoitusten tulkinnassa, varsinkin silloin kun käsikirjoitukseen on tehty paljon merkintöjä sen valmistumisen jälkeen. 
Partituuriin on vedetty tahtiviivat lyijykynällä, eikä niitä ole jälkikäteen vahvistettu musteella. Nuottien kirjoittamiseen käytetyn musteen laatu vaihtelee paljon jopa yhden sivun sisällä, mistä voi ehkä päätellä jotain työn hitaudesta. ${ }^{32}$

Paikoin nuotit on kirjoitettu yhdellä musteella ja legato-kaaret lisätty myöhemmin toisella musteella. Sivuilla 50-55 tämä ero on silmiinpistävä - säveltäjä on selvästikin myöhemmin korjaillut unohduksiaan, joita legato-kaarien lisäksi on ollut crescendo- ja diminuendo-kiiloissa sekä muissa dynamiikkamerkinnöissä (kuva 4).

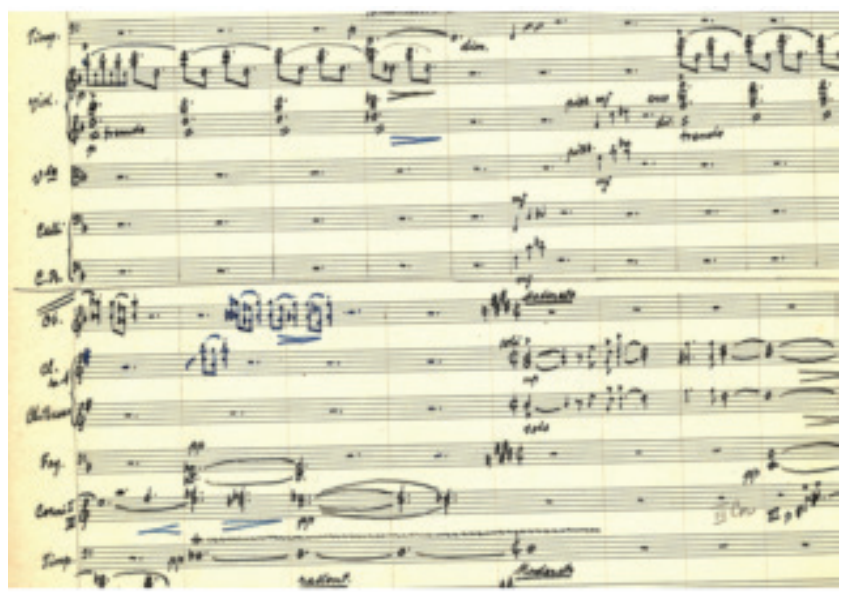

Kuva 4. Sinisellä musteella tehtyjä lisäyksiä B-partituurin sivulla 52.

Harjoitusnumerot on kirjoitettu lyijykynällä siististi pienin, ympyröidyin numeroin. Harjoituskirjaimet on sen sijaan lisätty vahvemmalla ja paksummalla lyijykynäjäljellä isosti ja selvästi huolettomammin. Toisesta osasta puuttuvat kokonaan harjoituskirjaimet $\mathrm{G}$ ja $\mathrm{H}$, jotka A-partituurissa ovat pois leikatuissa osuuksissa. Säveltäjän nuottikäsiala on selvästi erilaista kuin A-partituurissa. Alaspäiset nuotinvarret kiinnittyvät nyt lähes aina nuotinpään vasempaan reunaan, toisinaan ne ovat irti nuotin päästä ja suunnilleen keskellä. 1910-luvun puolivälin Madetojalle tyypillisiä johdonmukaisesti oikeaan reunaan kiinnittyviä nuotinvarsia ei B-käsikirjoituksessa juurikaan näy. Esittäjän merkintöjä on vähän. Joitakin eri instrumenttien sisääntuloja on vahvistettu vahvalla ja selkeällä käsialalla. Tämä käsiala voisi olla lyijykynänjäljestä päätellen sama, joka on lisännyt harjoituskirjaimet partituuriin. ${ }^{33}$

32 Madetoja kirjoittaa työn vaikeuksista vuoden 1943 päiväkirjassaan: "Kun kopioin I sinfoniaani, näen että huomiokykyni pettää tämän tästä. Ehtimiseen teen virheitä, vaikka koetan olla tarkkana."(28.6.1943.) "Kopioin I sinfoniaani. On sekava ja tuskallinen olo. En voi muuta kuin rukoilla Jumalaa antamaan apuansa."(31.7.1943.)

33 B-partituurissa ei varmaankaan ole valmistuttuaan ollut harjoituskirjaimia, vaan Fazer tai Madetoja on halunnut erottaa tämän edition HKO:n hallussa olevasta "vanhasta editiosta" siirtymällä kirjaimista numeroihin. Miksi kirjaimet on sitten jälkikäteen tähän partituuriin lisätty? Olisiko syynä se, että vuonna 1947 Jussi Jalas on esittänyt teoksen konsertissa Helsingin kaupunginorkesterin kanssa, ja orkesteri on saattanut haluta käyttää omasta nuotistostaan löytyviä nuotteja (PA) ja kapellimestari puolestaan siistimpää B-partituuria? Vastaus voisi löytyä vertailemalla B-partituuria Jussi Jalaksen käyttämiin partituureihin ja Jalaksen käsialaan. 


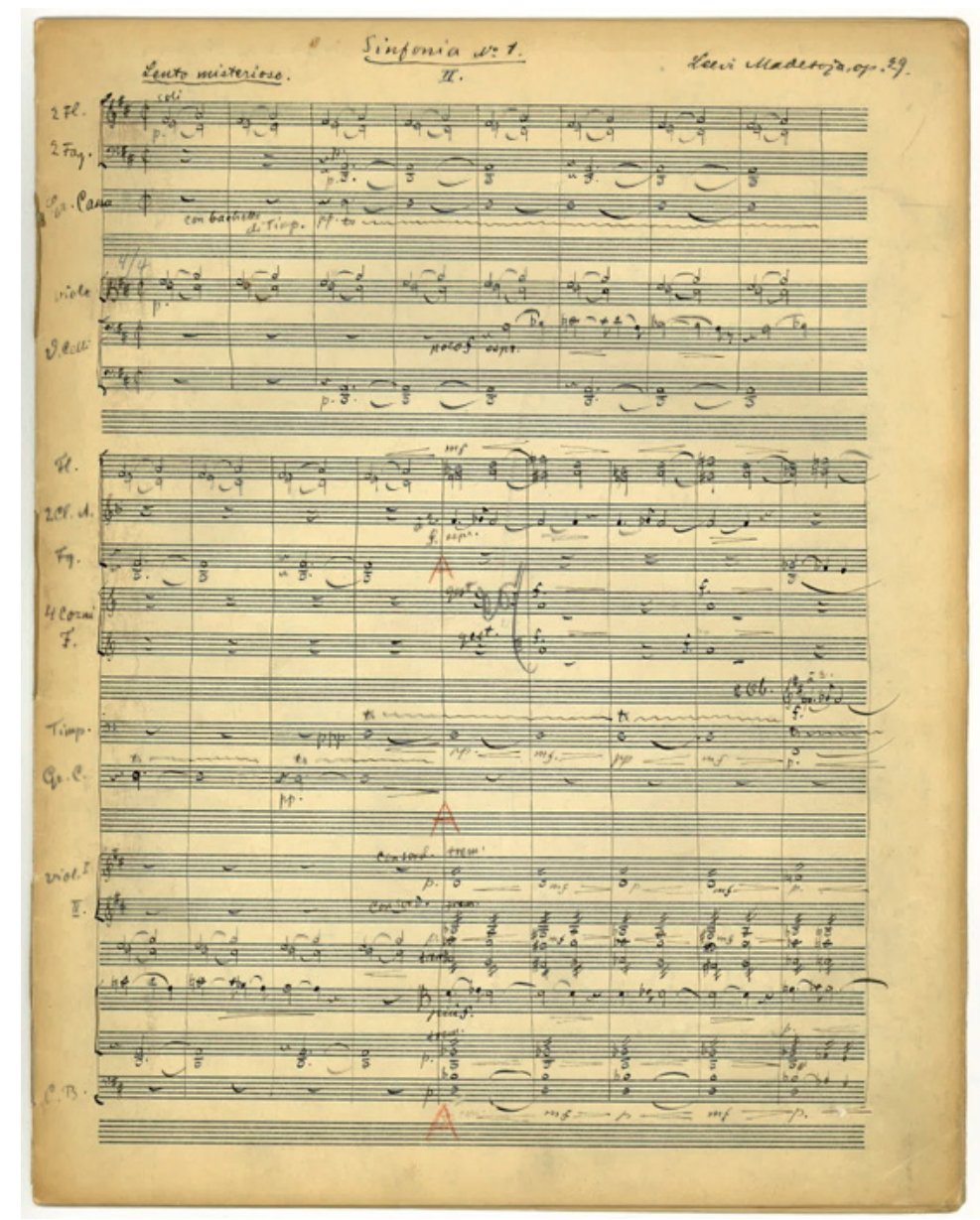

Kuva 5. Leevi Madetojan ensimmäisen sinfonian toisen osan "Lento misterioso" partituurikäsikirjoitus vuodelta 1916.

Lähde C sisältää ainoastaan sinfonian toisen osan "Lento misterioso" partituurin (kuva 5). Käsikirjoitus on tullut Kansalliskirjastoon 3.5.1972 Musiikin tiedotuskeskukselta, ja oletettavasti se on ollut säveltäjän omistuksessa 1910-luvulta lähtien tämän kuolemaan saakka. ${ }^{34}$

C-partituurin nuottipaperi on samaa Apostolin paperia, jota säveltäjä on käyttänyt A-partituurin toisen ja kolmannen osan kirjoittamiseen. Käsikirjoitus on kir-

34 Säveltäjän ja Arvo Räikkösen kirjeenvaihdon perusteella toisen osan käsikirjoitus on ollut säveltäjän hallussa 1930-luvulla, kun taas sinfonian täydellinen käsikirjoitus on ollut todennäköisesti HKO:lla - edes säveltäjä itse ei muistanut sen olinpaikkaa Eero Kososen sitä tiedustellessa. Arvo Räikkönen kirjoittaa kirjeessään Leevi Madetojalle 23.9.1933: "Olen jättänyt teiltä viimeksi saamamme käsikirjoitukset, II sinfonia, II osa I sinfoniasta, Alkusoitto op. 7 ja Pastorale veljelleni Sulo Räikköselle siinä mielessä, että hän toimittaa ne edelleen konservatorioon kirjastonhoitajalle." 
joitettu ruskeansävyisellä musteella, ja harjoituskirjaimet on A-partituurin tapaan kirjoitettu punaisella värikynällä. Lisäksi siellä täällä näkyy voimakkain lyijykynänvedoin tehtyjä kapellimestarin merkintöjä: instrumenttien sisääntuloja, jousituksia, numeroita muistuttamaan johtamiskaavasta sekä vahvistettuja esitysmerkintöjä. Merkintöjen niukkuudesta ja yhtenäisyydestä voi päätellä, että partituuri on ollut vain yhden esittäjän, eli todennäköisesti säveltäjän itsensä, käytössä.

Toiseen osaan tehdyt kaksi lyhennystä on merkitty oranssinpunaisella värikynällä, ja A-partituuria vastaava kolmen tahdin pituinen korjaus on tehty leikkaamalla pala nuottipaperia käsikirjoituksen viimeiseltä sivulta ja liimaamalla se sivulle 15 . Nuottikäsiala poikkeaa hieman käsikirjoituksen käsialasta, mutta toisaalta nuotinvarret kiinnittyvät nuotinpäiden oikeaan reunaan, kuten Madetojan 1910-luvun puolivälin käsialassa. Korjauslapun legato-kaaret on vedetty raskaalla ja hieman horjuvalla kädellä, toisin kuin ympäröivän nuottitekstin lennokkaat ja kevyet kaaret. ${ }^{35}$

Nuottipaperin ja nuottikäsialan perusteella partituurit A ja C on kirjoitettu samana ajanjaksona. Myös partituurien asettelu on ensimmäisellä sivulla lähes sama; ylempi partituuririvistö on A:ssa 6 riviä ja C:ssä 7 riviä korkea. Gran Cassa (isorumpu) on A:ssa kirjoitettu ensin ehkä vahingossa viivaston ylimpään väliin ja jatkossa toiseksi ylimpään väliin, kun C:ssä se on keskimmäisellä nuottiviivalla. C:n ylemmästä partituuririvistöstä on Gran Cassan riviltä unohtunut tauko, mutta jatkossa se on yhteneväinen A:n kanssa. C:ssä on ensimmäisellä sivulla yksi tahti enemmän kuin A:ssa, mutta siitä eteenpäin nuottiviivastojen sommittelu pysyy täysin samana sivulle 11 saakka.

C:n sivulla 11 on Madetoja nuottipaperia säästääkseen siirtynyt käyttämään kahta partituuririvistöä instrumentaation pienentyessä. Tästä voi päätellä, että C on kopioitu A:sta, sillä jos A on se käsikirjoitus, johon Madetoja tyypilliseen tapaansa ensin luonnosteli sävellyksen lyijykynällä, ei hän siinä vaiheessa välttämättä vielä ollut lyönyt lukkoon instrumentaation muutoksia eikä siten voinut olla samalla tavalla säästeliäs paperin käytön suhteen kuin valmiin teoksen kopioija (ks. kuvat 6a ja 6b).

Seuraava, vieläkin paljastavampi eroavaisuus löytyy C:n sivun 15 alemmasta partituuririvistöstä. Sivunkäännön jälkeen sivulla 16 ei Gran Cassalla enää ole nuottiriviä, vaikka A:ssa se jatkuu aina patarumpujen sisääntuloon saakka. Jos C olisi säveltäjän alkuperäinen käsikirjoitus, ei hän olisi voinut unohtaa kopioida Gran Cassaa sivun vaihtuessa. Sivun 16 alemmassa partituuririvistössä Madetoja on kirjoittanut Gran Cassan tremolon samalle viivastolle kuin patarummut, mutta on unohtanut lisätä sen ylempään rivistöön, johon se olisi kyllä mahtunut käyrätorvien ja jousien väliin (kuva 7).

35 Madetojan nuottikäsialan muutoksiin tarkemmin tutustumalla olisi ehkä mahdollista saada summittainen ajoitus tälle lisäykselle, mutta siihen ei tämän artikkelin puitteissa ollut mahdollisuutta. Se voidaan joka tapauksessa sanoa, että tämä lisäys on tehty ennen B-partituurin kirjoittamista. Säveltäjä on ehkä tehnyt muutoksen hallussaan olevaan partituuriin joskus 1930-luvulla ja sementoinut muutoksen myös A-partituuriin, kun siihen kustannussopimukseen liittyneen kopiointityön kautta tarjoutui tilaisuus. 


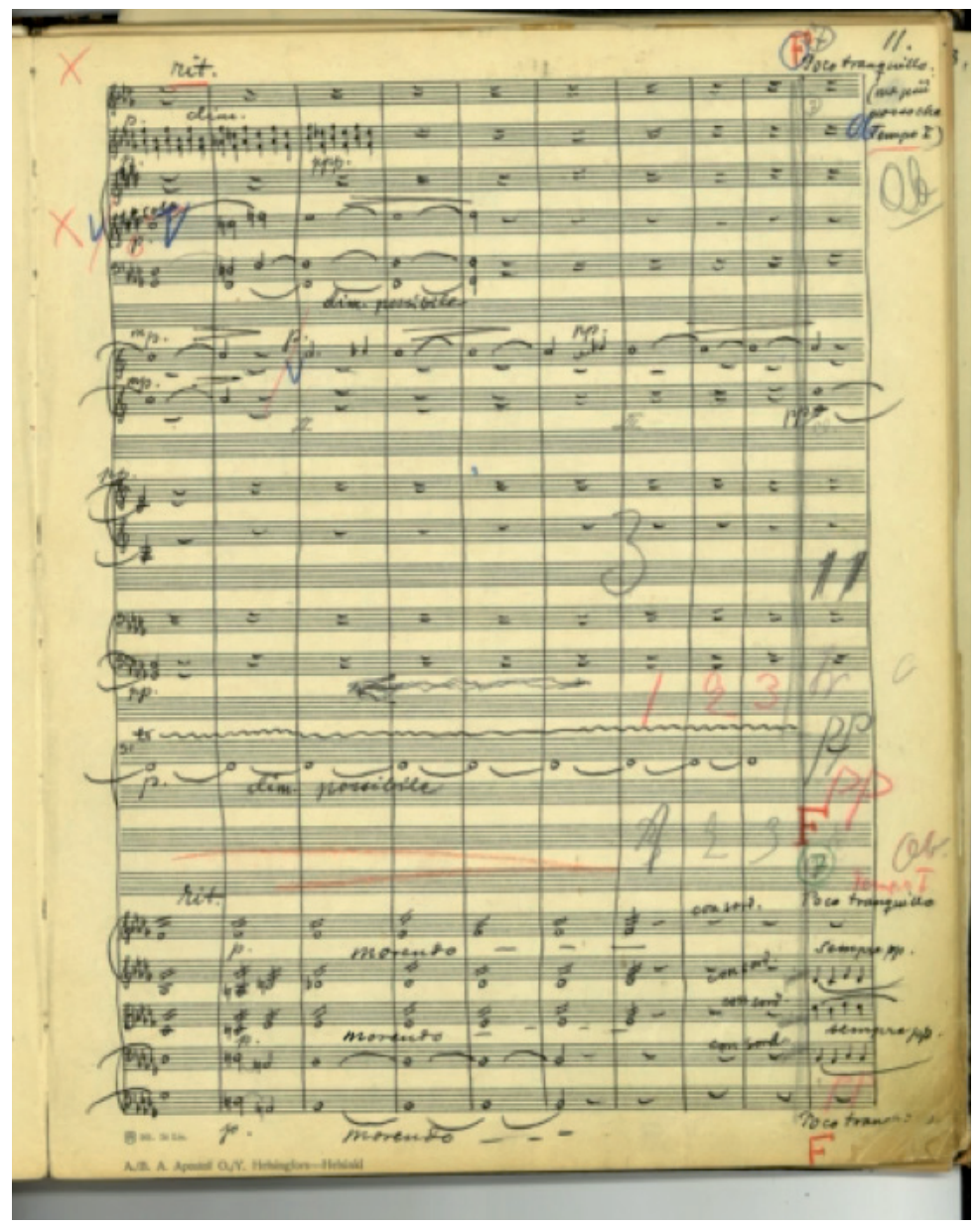

Kuva 6a. Sinfonian toisen osan sivun 11 sommittelu partituurikäsikirjoituksessa A.

Alkuperäisen partituurikäsikirjoituksen (A) tulkintaa vaikeuttaa se, että siinä on päällekkäin monta eri tekstikerrostumaa: varsinainen kantaesityksen teksti, sen alla näkyvät luonnokset ja toteutumattomat variantit, esitysten yhteydessä tehdyt korjaukset, eri kapellimestarien merkinnät, säveltäjän vuosien saatossa tekemät muutokset sekä nuottien kopioimiseen liittyvät toimitukselliset merkinnät. Vuoden 1943 partituuri (B) on puolestaan puutteellinen monilta osin artikulaation ja dynaamisten merkintöjen osalta ja sisältää myös suoranaisia virheitä. Partituurilähteistä $\mathrm{C}$ on kaikkein ongelmattomin, koska se on säveltäjän omakätinen puhtaaksikirjoitus, jota eivät hämmennä luonnostelun jäljet eivätkä myöskään useiden esittäjien merkinnät.

Leevi Madetojalla on ollut monenlaisia rooleja käsikirjoituksensa muokkaajana. Sen lisäksi, että hän on teoksen säveltäjä, on hän toiminut sen esittäjänä kantaesityk- 


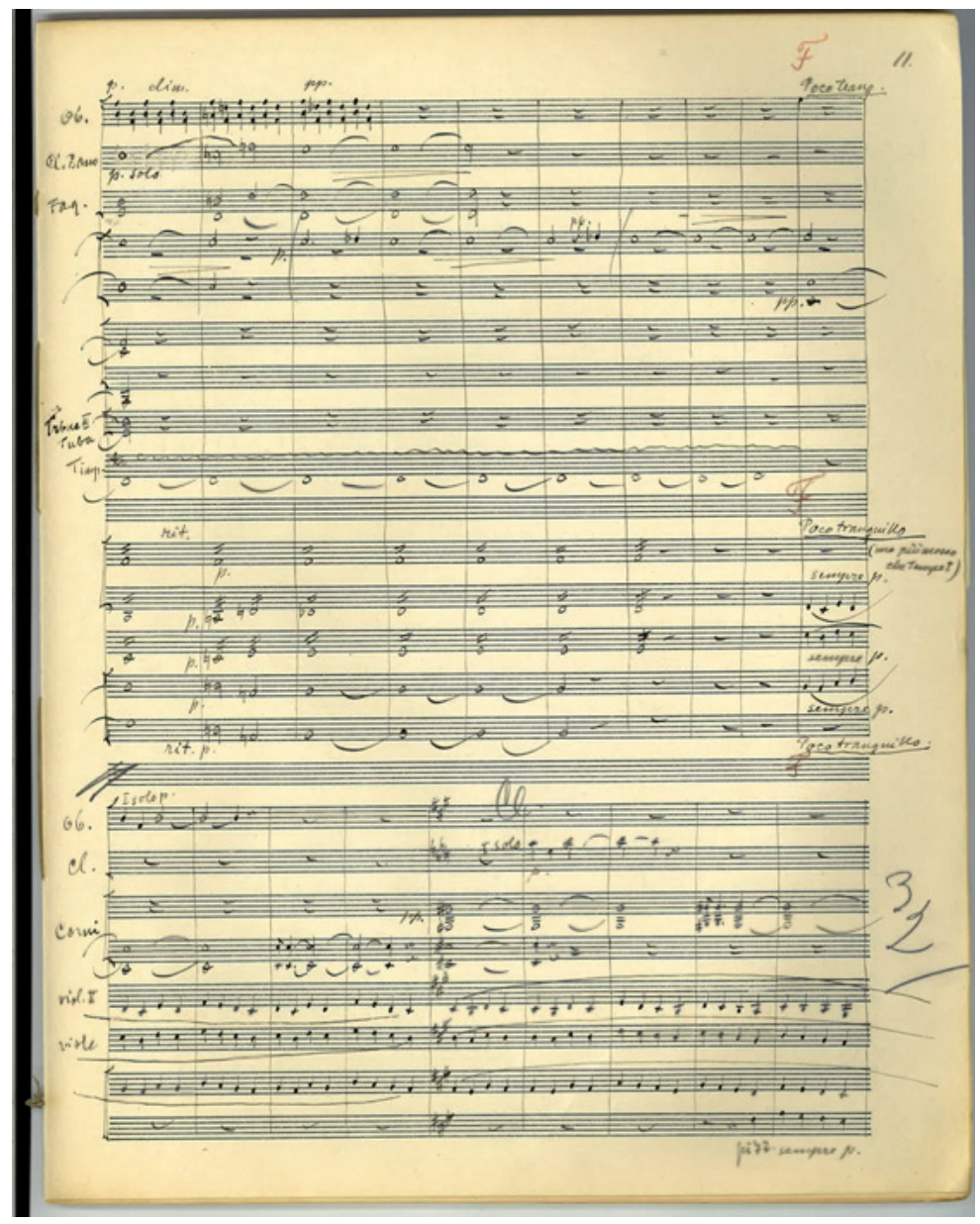

Kuva 6b. Sinfonian toisen osan sivun 11 sommittelu partituurikäsikirjoituksessa C.

sestä ainakin 1930-luvulle asti. Tämän lisäksi hän on toiminut itse sekä partituurien C että B puhtaaksikirjoittajana ja tavallaan myös vuoden 1943 partituurin (B) editorina päättäessään, mitkä muokkauksista otetaan mukaan teoksen kustannettuun versioon.

Partituurikäsikirjoitusten sijoittaminen lähdeketjuun (kuva 8) on varsin kiistatonta. A on päiväyksensä ja näkyvissä olevan luonnostelun perusteella säveltäjän alkuperäinen käsikirjoitus vuodelta 1916. Toisen osan erillinen partituuri C on varmuudella kopioitu lähteestä $A$, ja käytetyn nuottipaperin perusteella kopiointi on tapahtunut hyvin lähellä teoksen sävellysaikaa - siksi ajoittaisin myös sen vuoteen 1916. ${ }^{36}$ Myös partituuri B on kopioitu lähteestä A, mutta päiväyksen puuttuessa ko-

36 Kun tietää, miten valtavassa kiireessä Madetoja työskenteli ennen vuoden 1916 kantaesitystä, on syytä olet- 


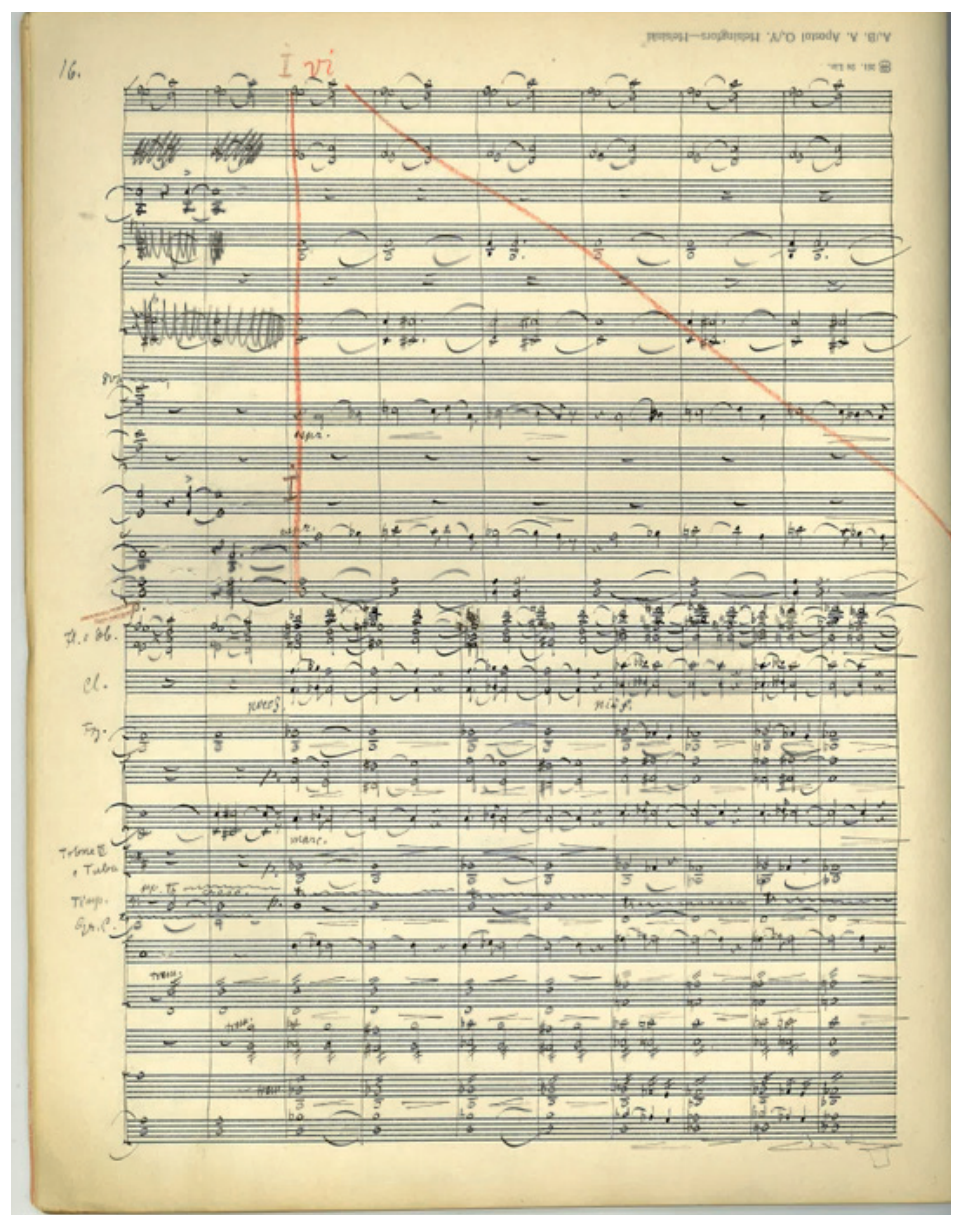

Kuva 7. Sivun vaihtumisen jälkeen kopioimatta jäänyt isorummun rivi (partituuri C). Huomaa myös punakynällä merkitty pääteeman kertauksen poisto.

pioimisajankohdan selvittäminen oli haasteellista. Partituuriin kirjoitetuista esityspäivämääristä ensimmäiset ovat 1930-luvulta, mistä olisi luonnollista päätellä, että myös partituuri on 1930-luvulla kopioitu. Madetojan kirjeenvaihto kuitenkin todistaa, että kapellimestari Eero Kososen harkitessa sinfoniaa Tampereen orkesterin kauden 1933 ohjelmaan ei B-partituuria ollut vielä olemassa, vaan säveltäjä ohjeisti Kososta pyytämään partituuria lainaksi HKO:lta. ${ }^{37}$ Madetojan päiväkirja (kuva 2)

taa, että teoksen toisen osan kopioiminen on tapahtunut vasta kantaesityksen jälkeen, kun säveltäjän aikataulut sen ovat sallineet. Siksi C-partituurin olemassaolo osaltaan tukee sitä käsitystä, että sinfonia on kantaesityksessään soitettu lyhentämättömänä - muutenhan säveltäjä olisi voinut jättää kyseiset tahdit pois jo tätä kopiota tehdessään.

37 "Kolmesta sinfoniasta on ensimmäinen luullakseni teknillisesti helpoin. Siihen kuuluvat nuotit ovat H-gin Kaupunginorkesterilla. Jos partituuria ei mahdollisesti siellä olisi, löytynee se sitten pankkiholvista, jossa mi- 


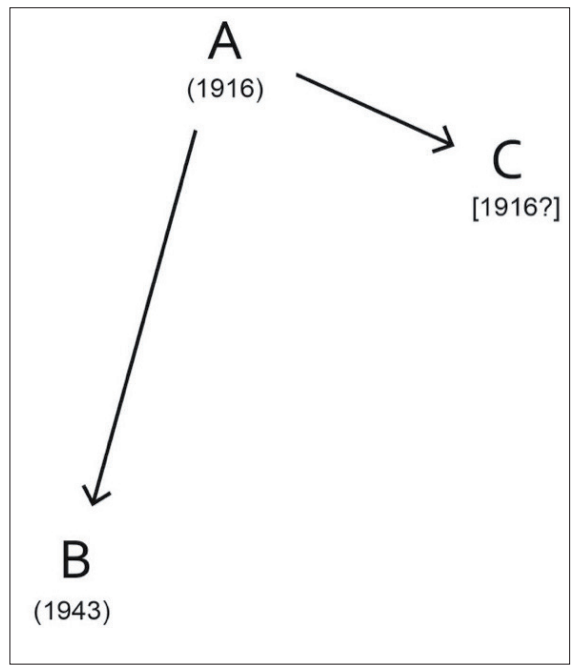

Kuva 8. Partituurikäsikirjoitusten lähdepuu.

puolestaan osoittaa lopullisesti, että hän ponnisteli B-partituurin kopioimisen parissa vuonna 1943 yrittäessään kaupata sen kustannusoikeuksia Fazerille.

\section{ORKESTERIN ÄÄNILEHTIEN KUVAILU JA SIJOITTAMINEN LÄHDEKETJUUN}

Madetojan ensimmäisen sinfonian käsin kirjoitetut orkesterimateriaalit muodostavat kolme eri lähdekokonaisuutta. Partituurin A yhteyteen kuuluvat orkesteriäänet olen nimennyt lyhenteellä $\mathrm{PA}$ ja partituurin $\mathrm{B}$ orkesteriäänet $\mathrm{PB}$. Erilliset toisen osan "Lento misterioso" orkesteriäänet olen nimennyt lyhenteellä PC, koska ne todennäköisesti on kirjoitettu partituurin C kanssa käytettäviksi. Nostan seuraavaksi esiin äänilehdistä ilmeneviä yksityiskohtia, jotka liittyvät niiden ajoitukseen, esittäjien tekemiin muokkauksiin ja muihin merkillepantaviin seikkoihin.

Sinfonian alkuperäisen partituurikäsikirjoituksen (A) yhteyteen kuuluvat orkesteriäänet (PA) jakautuvat seuraaviin alakategorioihin: PA-1 Helsingin kaupunginarkistossa säilytettävä HKO:n alkuperäinen orkesterimateriaali ja kaksi Kansalliskirjastoon päätynyttä HKO:n leimoilla varustettua äänilehteä, PA-2 Kansalliskirjaston leimattomat äänilehdet, PA-3 HKO:n materiaaliin todennäköisesti 1920-luvulla lisätyt ykköspulttien äänilehdet sekä PA-4 HKO:n materiaaliin kuuluva Kusti Aerilan $^{38}$ puhtaaksikirjoittama äänilehti.

PA-1 on Madetojan ensimmäisen sinfonian kantaesityksessä 10.2.1916 käytetty

nulla vuokratussa lokerossa on käsikirjoituksiani säilössä.” Leevi Madetojan kirje Eero Kososelle 29.12.1932. 38 Kusti Aerila (1876-1959) oli HKO:n I klarinetisti ja puhtaaksikirjoitti paljon nuotteja etenkin 1920-1930-luvuilla (Piippo-Fair 1990, 67). 


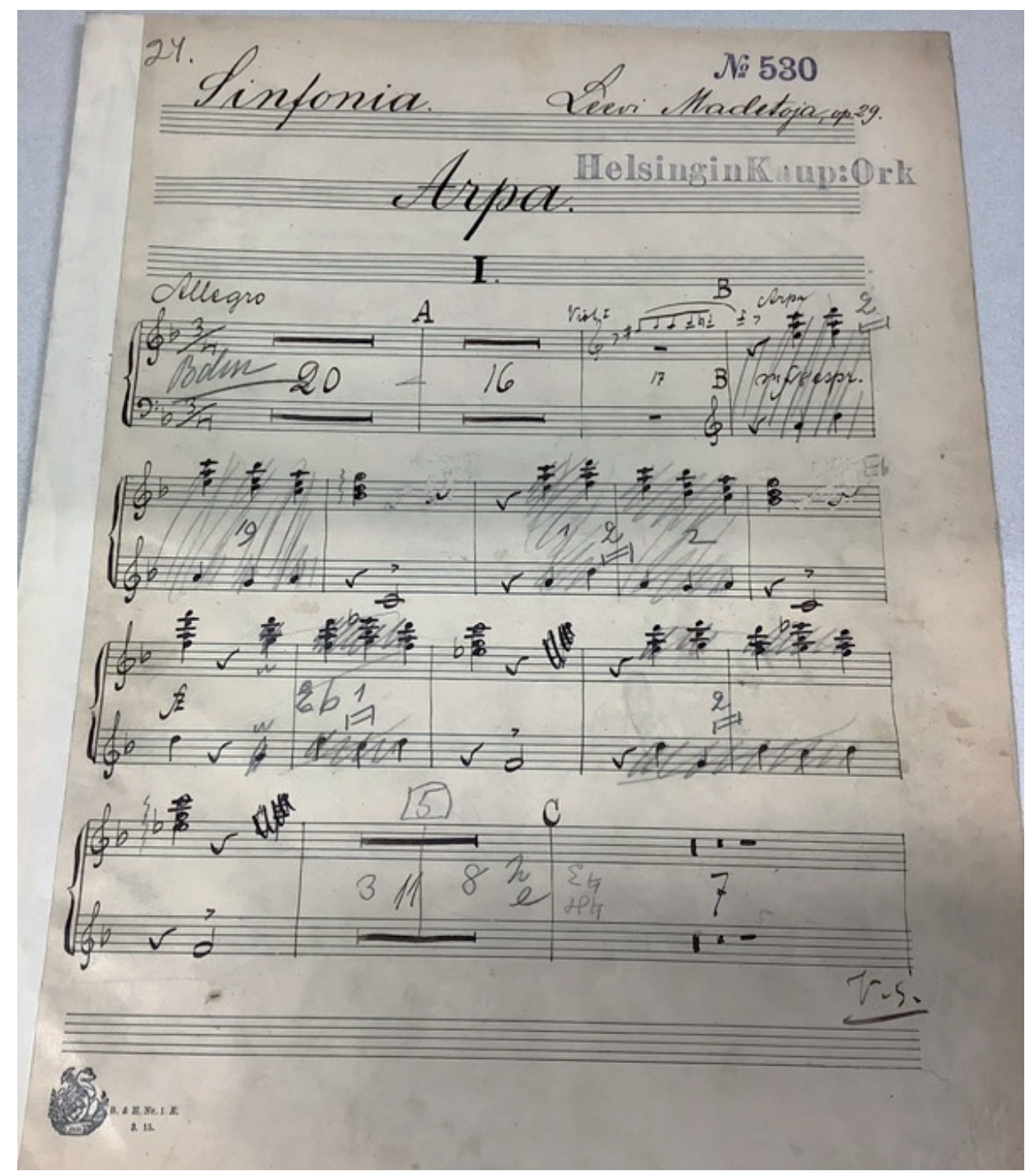

Kuva 9. Harpun äänilehti HKO:n alkuperäisestä orkesterimateriaalista PA-1.

HKO:n orkesterimateriaali lisäkopioineen. ${ }^{39}$ Siihen kuuluu 43 HKO:n leimoin varustettua äänilehteä, joista 41 sijaitsee Helsingin kaupunginarkistossa ja 2 lisäkopiota Kansalliskirjastossa. Kaupunginarkiston äänilehdet on piirretty B\&H:n 12-viivaiselle nuottipaperille. Puhaltajien, lyömäsoitinten ja harpun äänilehdet ovat yhden kopistin käsialaa, mutta jousten äänilehdissä näkyy useita eri käsialoja. ${ }^{40}$ Puhaltimi-

39 Nämä äänilehdet ovat olleet käytössä kaikissa sinfonian esityksissä 1940-luvulle saakka, pois lukien ne mahdolliset vain toisen osan "Lento misterioso" esitykset, joissa on käytetty orkesteriääniä PC.

40 Kopistin henkilöllisyyden selvittäminen voi perustua signeeraukseen, laskuun kopioinnista tai vertailuun ni- 
en, lyömäsoittimien ja harpun äänilehdet on numeroitu lyijykynällä numeroin 1-24 ensimmäisen nuottisivun vasempaan yläkulmaan (kuva 9). Jousisoitinten äänilehdille on annettu sektiokohtaiset pulttinumerot - ne olen omassa luokituksessani ilmoittanut kunkin äänilehden kohdalla alaindeksillä. Lähes kaikissa äänilehdissä näkyy Madetojan käsialalla tehtyjä muokkauksia, erityisesti sinfonian kolmannessa osassa. Vaskien osuuksia on muokattu finaalissa useaan otteeseen, ja osan loppuun on kirjoitettu kaikille instrumenteille yhdeksän tahdin pituinen lisäys.

Ensiviulujen kolmospultin äänilehdessä (PA-1 v11 $1_{3}$ ) on paljon jousitusmerkintöjä, ja lisäksi toisessa osassa on raaputtamalla ja suttaamalla tehtyjä korjauksia ja toisen osan lyhentämiseen liittyvät puna- ja sinikynällä merkityt hypyt harjoituskirjaimien G ja I kohdalla. Sivulle 8 on liimattu lappu, jossa on korjaus toisen osan lyhennetyn version ylimenoon. Kopistin virheitä on korjattu sivuilla 11 ja 12, ja äänilehden lopussa on soittajien lisäämiä esityspäivämääriä.

Toisten viulujen ykköspultin äänilehteen $\left(\mathrm{PA}-1 \mathrm{vl} 2_{1}\right)$ on tehty myöhempää Bpartituuria vastaavia korjauksia muun muassa ensimmäisten tahtien sävelten pituuksiin, ja harjoitusnumerot on lisätty lyijykynällä. Toisen osan leikkaukset on merkitty puna- ja sinikynällä ja ylimenotahdit piirretty kolmannen osan otsikkoriville. Jousituksia ja muita esittäjän merkintöjä on runsaasti.

Toisen sellopultin äänilehdessä (PA-1 vc $)$ on toisen osan alkuun merkitty "solo" jokaisen jaetun rivin alussa, mutta lyijykynällä on tehty korjaus "div. à 2". Molemmat leikkaukset toiseen osaan on merkitty puna- ja sinikynällä. Kolmannen sellopultin äänilehdessä (PA-1 vc $\left.\mathrm{v}_{3}\right)$ toisen osan alun "Solo" on korjattu muotoon "soli". Neljännen sellopultin äänilehdessä $\left(\mathrm{PA}-1 \mathrm{vc}_{4}\right)$ on toisen osan alun sellomelodia merkitty alkamaan vetojousella, kun muissa äänilehdissä on työntöjousen merkki. ${ }^{41}$

Kansalliskirjastoon kulkeutuneet irralliset $\mathrm{HKO}: \mathrm{n}$ orkesterimateriaalin äänileh$\operatorname{det}\left(\mathrm{PA}-1 \mathrm{vla}_{\mathrm{KK} 4}\right.$ ja PA-1 $\left.\mathrm{kb}_{\mathrm{KK} 3}\right)$ : on kirjoitettu samalle B\&H-nuottipaperille kuin muutkin PA-1-materiaalin jousisoittimet. Kumpaankaan äänilehteen ei ole merkitty toisen osan lyhennyksiä, mutta viimeisen osan lopun yhdeksän tahdin pidennys on niissä valmiiksi puhtaaksikirjoitettuna.

Kansalliskirjastossa on myös kolme leimaamatonta äänilehteä (PA-2) joissa ei ole toisen osan lyhennyksiä. ${ }^{42}$ Ensiviulun (PA-2 vl1) ja alttoviulun (PA-2 vla $)$ äänilehdet on kirjoitettu todennäköisesti saman kopistin toimesta merkittömälle ja vesileimattomalle paperille (kuva 10). Toinen alttoviulun äänilehti (PA-2 vla $)$ on eri kopistin käsialaa; nuottikäsiala on siistiä, nuotinvarret kiinnittyvät enimmäkseen nuotinpään oikeaan reunaan ja harjoituskirjaimet on lisätty äänilehteen punaisella

meltä tunnettujen kopistien nuottikäsialan kanssa. Kantaesityksessä käytettyjen äänilehtien kopisteja ei tunneta. 41 Tämä äänilehti on alkuperäisessä materiaalissa ollut ykköspultin äänilehti ennen äänilehtien PA-3 kirjoittamista. Ks. myös kapellimestari Arvo Volmerin kommentti kyseisen melodian fraseerauksesta (Mäkilä 2020, 91). 42 Kansiossa on kolme äänilehteä (1. viulu ja kaksi alttoviulun äänilehteä), joissa ei ole HKO:n leimaa. Ne saattavat olla jotain Helsingin ulkopuolella tapahtunutta esitystä varten kopioituja äänilehtiä tai sitten myöhemmin kirjoitettuja lisä- tai harjoittelukopioita, joihin vain ei ole syystä tai toisesta lyöty kaupunginorkesterin leimoja. 


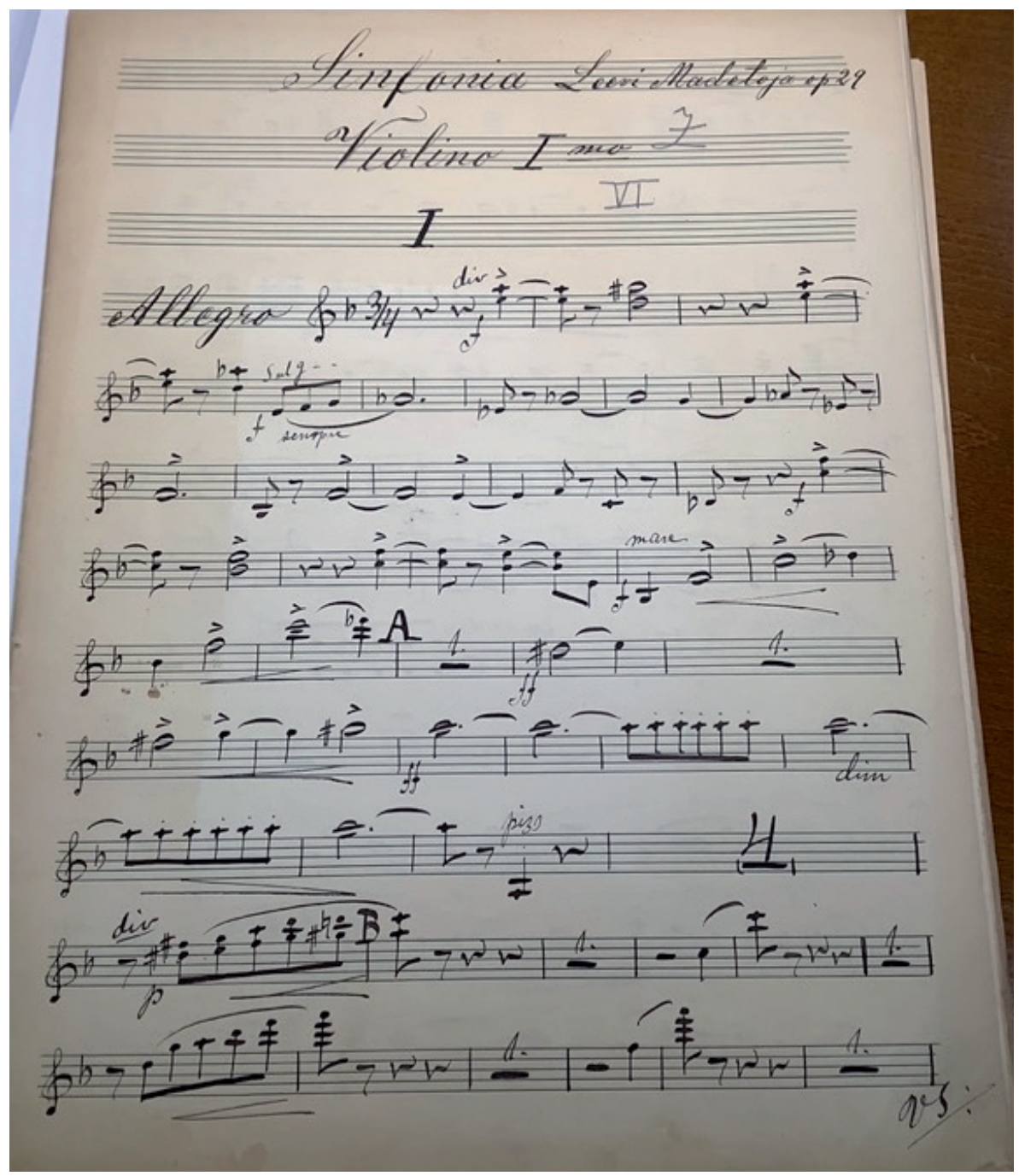

Kuva 10. Ensiviulun leimaamaton äänilehti PA-2 vl1, Kansalliskirjasto.

värikynällä ja samantyylisellä käsialalla kuin C-partituurin harjoituskirjaimet. ${ }^{43}$

Lähde PA-3 muodostuu Lauri Nissisen kopioimista, HKO:n orkesterimateriaaliin myöhemmin lisätyistä viidestä äänilehdestä (kaksi ensiviulun äänilehteä ja yk-

43 Tämän äänilehden käsialassa on useita yhtymäkohtia Madetojan käsialaan, mutta pelkkien yhtäläisyyksien perusteella on mahdotonta kiistattomasti päätellä kirjoittajaa. Tunnistamisen kannalta tärkeämpää on "selittämättömien merkittävien erojen puute" (Edge 2001, 228-229). Työstän parhaillaan myös artikkelia Leevi Madetojan nuottikäsialasta ja sen muutoksista noin neljänkymmenen vuoden ajanjaksolta, eli tähän kysymykseen voidaan hyvinkin saada vastaus sitten, kun tarpeeksi suuri määrä nuottiaineistoa on käyty läpi. Tämän artikkelin puitteissa se ei ollut mahdollista. 


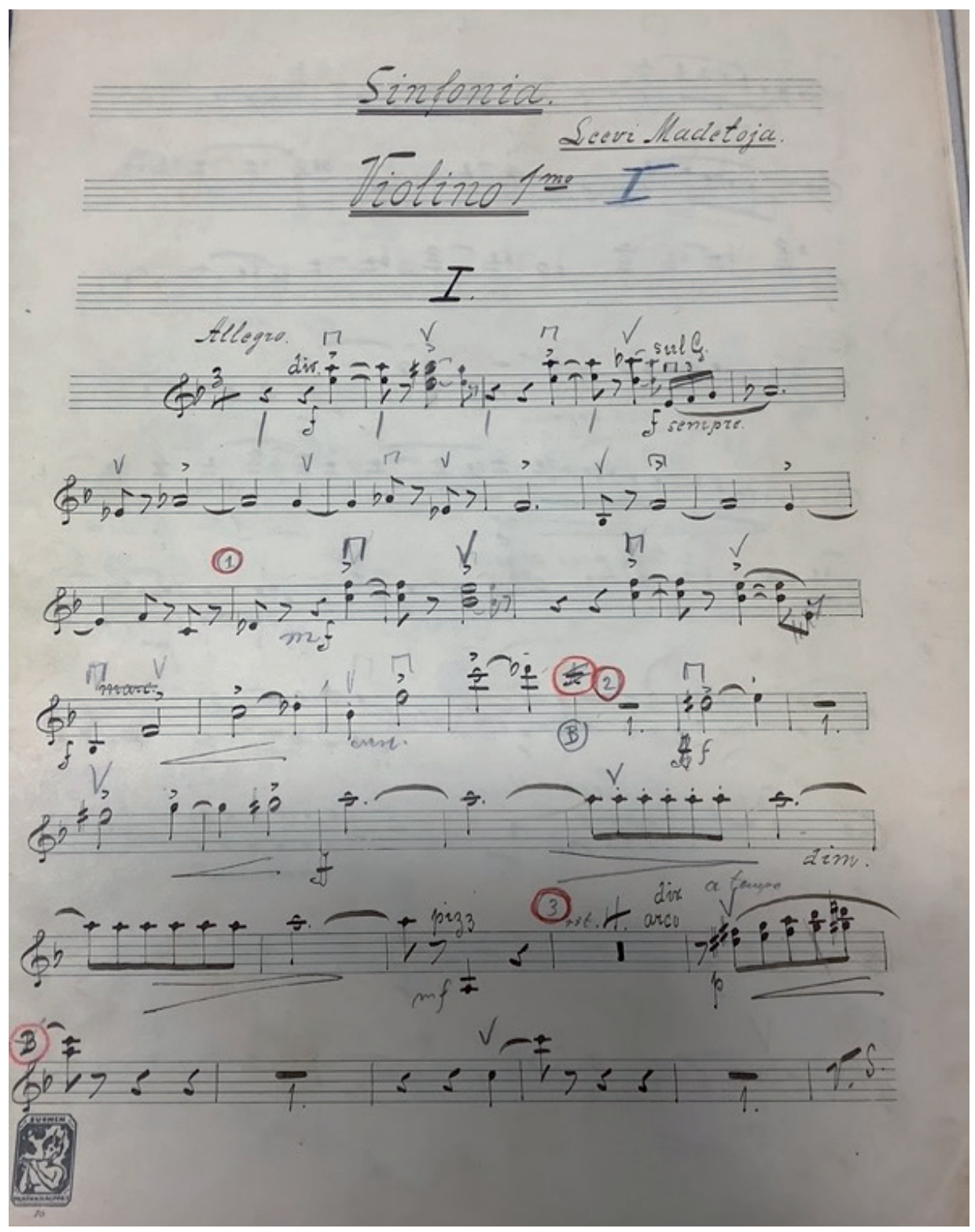

Kuva 11. Lauri Nissisen kopioima ensiviulun äänilehti PA-3 vl1 $1_{1}$ Kaupunginarkisto.

sittäiset alttoviulun, sellon ja kontrabasson äänilehdet). ${ }^{44}$ Nuottiarkkien vasemmassa alakulmassa on liikemerkki, jossa on huilua soittava satyyri ja teksti "SUOMEN

44 Lauri Nissinen (1885-1956) oli HKO:n kontrabasisti vuosina 1917-1952 ja suosittu nuottien puhtaaksikirjoittaja (Piippo-Fair 1990, 69). 
MUSIIKKIKAUPPA OY" ${ }^{45}$ Viimeisen tahdin perässä on teksti "Kop. Lauri Nissinen”. Äänilehdissä ei ole HKO:n leimoja, vaikka ne onkin käsin numeroitu osaksi HKO:n materiaalia.

Nissisen kopioimassa ensiviulun ykköspultin äänilehdessä (PA-3 vl1 $1_{1}$ ) on A:n mukaiset harjoituskirjaimet, ja siihen on lisätty myöhemmin lyijykynällä harjoitusnumerot, jotka on ympyröity punaisella värillä (kuva 11). Samalla punaisella värillä on merkitty leikkaus sinfonian toiseen osaan äänilehden sivulla kahdeksan. Tältä sivulta on myös raaputettu pois lopun Lentoa edeltävät tahdit ja kirjoitettu uusi kolmen tahdin ylimeno niiden päälle. Korjauksen nuottikäsiala on eri käsialaa kuin muu nuottiteksti, ja se saattaa olla myös Madetojan käsialaa. ${ }^{46}$

Huomionarvoista on, että tästä äänilehdestä on jo valmiiksi jätetty pois harjoituskirjain $\mathrm{G}$, josta partituurissa alkaa toisen osan lopullisesta versiosta poistettu fis-duuriepisodi. Toinen poisto, eli pääteeman kertaus harjoituskirjaimessa I on kirjoitettu ulos, ja se on yliviivattu myöhemmin punakynällä. Äänilehdestä voidaan siis päätellä seuraavat seikat: (1) tämä leimaamaton äänilehti on kirjoitettu eri aikaan kuin HKO:n muu materiaali (PA-1), jossa molemmat leikkaukset ovat näkyvissä luultavimmin 1920-luvulla; (2) leikkauksia ei ole tehty samaan aikaan. Madetoja on oletettavasti ensin lyhentänyt osaa poistamalla harjoituskirjaimesta $G$ alkavan fis-duuriepisodin ja säveltänyt sen paikalle kolmen tahdin ylimenon. Vasta myöhemmin hän on päättänyt lyhentää osaa edelleen jättämällä pois pääteeman kertauksen harjoituskirjaimessa I. ${ }^{47}$ Selvittämättä jää vielä se, mihin aikaan muutokset on tarkalleen ottaen tehty. Tähän äänilehteen on lisäksi tehty paljon B-partituurin mukaisia muutoksia, joten sitä on mahdollisesti muokattu malliksi Fazerin orkesterimateriaalin PB piirtäneelle kopistille. Muissa viulujen äänilehdissä ei näy vastaavia muutoksia (kuten tahtien 2 ja 14 puolinuottien lyhentämistä, ks. kuva 11).

Ensiviulun kakkospultin äänilehteen (PA-3 vl1 ${ }_{2}$ ) sekä alttoviulun (PA-3 vla $)$, sellon (PA-3 $\left.\mathrm{vc}_{1}\right)$ ja kontrabasson (PA-3 $\mathrm{kb}_{1}$ ) äänilehtiin on kaikkiin lyijykynällä lisätty harjoitusnumerot. Toisen osan alun sellon ylädivisin kohdalla on lukenut alun perin "solo", ja nuottiin on se musteella korjattu muotoon "soli". Rivin alussa lukee "div. à 2" puhtaaksikirjoittajan käsialalla. ${ }^{48}$

45 Vuonna 1923 perustetusta Suomen Musiikkikauppa Oy:stä löytyy Sanomalehtiarkistosta runsaasti mainintoja 20-luvulta, ja toimintaa sillä on ollut Viipurissa ja Helsingissä.

46 Ennen kuin tutkimukseni Madetojan nuottikäsialasta on valmis, ei korjausten kirjoittajasta voi sanoa mitään lopullista. On kuitenkin hyvin todennäköistä, että kun julkaisemattomaan, vain käsikirjoitusmuodossa olevaan teokseen tehdään rakenteellisia muutoksia, muutokset kirjoittaa äänilehtiin säveltäjä itse. Jos toisen osan lyhentäminen on tehty Madetojan omaa konserttia silmällä pitäen, on hän todennäköisesti tehnyt korjaukset omakätisesti kaikkiin äänilehtiin.

47 Väliversion olemassaolon (jossa ensimmäinen leikkaus on tehty, mutta toista ei) voisi kriittiseen editioon dokumentoida esimerkiksi siten, että jälkimmäinen hyppy on nuoteissa vaihtoehtona koodamerkillä merkittynä. 48 Näyttää siltä, että puhtaaksikirjoittajat ovat kaikki aluksi tulkinneet sellorivin soolona, mutta se on harjoituksissa korjattu koko sektion sooloksi (soli). Onko kyseessä puhtaaksikirjoittajan sekaannus vai säveltäjän päättämättömyys, sitä on mahdoton sanoa. Joka tapauksessa käsikirjoitukset A ja C antavat olettaa, että melodia 
PA-4 on Kusti Aerilan piirtämä toisen viulun viitospultin lisäkopio. Kopioon on jälkikäteen merkitty kaksi leikkausta toiseen osaan ja korjattu ylimeno raaputtamalla, eli kopioimisen aikaan (oletettavasti 1920-luvulla) teosta on vielä soitettu täydessä pituudessaan. Käsin kirjoitetut lisäkopiot on käytännössä aina kopioitu toisesta äänilehdestä eikä partituurista.

Toisesta osasta pois leikatuissa osuuksissa on PA-materiaalissa runsaasti jousitusmerkintöjä, mikä myös osaltaan todistaa, että teosta on näistä äänilehdistä soitettu alkuperäisessä, lyhentämättömässä asussaan.

Harpun osuudesta (kuva 9) on 12 tahtia materiaalissa PA sutattu yli kokonaan tai osittain, mutta itse olen täysin vakuuttunut siitä, että nuo tahdit on teoksen kantaesityksessä soitettu. ${ }^{49}$ Syynä tahtien myöhempään poistamiseen on saattanut olla esimerkiksi se, että orkesterin harpisti ei ole pystynyt niitä soittamaan kapellimestarin haluamassa tempossa. Kyseisessä kohdassa partituurissa harppu on kuitenkin merkitty mf espr., kun taas sitä säestävät puupuhaltimet soittavat piano! Jos halutaan arvailla säveltäjän alkuperäistä intentiota, esitysmerkinnöistä on johdettavissa, että harpun tulisi olla näissä tahdeissa keskeisessä roolissa. Yhdessä sutatuista tahdeista on harpistin lyijykynällä lisäämä muistutus es-sävelestä, mikä myöskin todistaa sen puolesta, että tahdit on teoksen ensimmäisissä esityksissä soitettu. Oma mielipiteeni on, että tahdit tulisi sinfonian kriittisessä editiossa palauttaa varsinaiseen nuottitekstiin ja dokumentoida niiden myöhempi poistaminen kriittisessä kommentaarissa..$^{50}$

Lähde PB sisältää sinfonian vuoden 1944 paikkeilla käsin kirjoitetut orkesteriäänet. ${ }^{51}$ Äänilehtiä on valitettavasti säilynyt vain neljä: viulu 1 (kuva 12), viulu 2 ja kaksi kontrabasson äänilehteä. Äänilehdistä kaksi on yhden kopistin käsialaa ja kaksi muuta eri kopistien eri nuottipaperilaadulle piirtämiä. Äänilehdissä on harjoitusnumerot musteella kirjoitettuna, mutta ei A:n mukaisia harjoituskirjaimia. Ensiviulun äänilehdessä $\left(\mathrm{PB}\right.$ vl1 $\left.1_{5}\right)$ on merkintöjä lyijykynällä ja sinisellä värikynällä, ja muutama tahtilajin vaihdos on lisäksi ympyröity punaisella. Toisessa kontrabasson äänilehdessä $\left(\mathrm{PB} \mathrm{kb}{ }_{1}\right)$ on nähtävissä lyijykynämerkintöjä, ja muutama esitysmerkin-

on tarkoitettu sektion soitettavaksi, ja näin sitä on ehkä teoksen ensimmäisten esitysten aikaan esitettykin. Jossain vaiheessa on sitten siirrytty esittämään melodia soolosellon soittamana.

49 Jopa musiikkikriitikko Evert Katila (1872-1945) kirjoittaa pian sinfonian kantaesityksen jälkeen Tidning for Musik -lehdessä julkaistussa teosesittelyssään huilujen, oboeiden ja harpun leikkisästä sivuaiheesta: "Det lekande sidomotivet i F-dur (2) som sakta och i lugnare tempo upptages af flöjter, oboer och harpa på en utdragen hornton [...]" (Katila 1916, 25).

50 Todistin myös omin korvin lokakuussa 2020 johtamissani Helsinki Metropolitan Orchestran harjoituksissa ja konsertissa, miten kauniisti kyseinen teema soi, kun harpun osuus soitetaan alkuperäisessä muodossaan. Esitimme tuolloin sinfonian ensimmäisen ja toisen osan tutkimustyöhöni perustuvista orkesterimateriaaleista.

51 Fazer kirjoitutti sinfoniasta vuokranuotistoaan varten uudet orkesteriäänet, koska alkuperäiset kuuluivat HKO:lle. Äänilehdet on kopioitu HKO:n materiaalista (PA), mutta harjoituskirjaimien tilalle on vaihdettu harjoitusnumerot. Todennäköisesti kopiointi on tapahtunut pian sen jälkeen, kun Madetoja toimitti sinfonian uuden puhtaaksikirjoituksen (B) Fazerille 16.12.1943. 


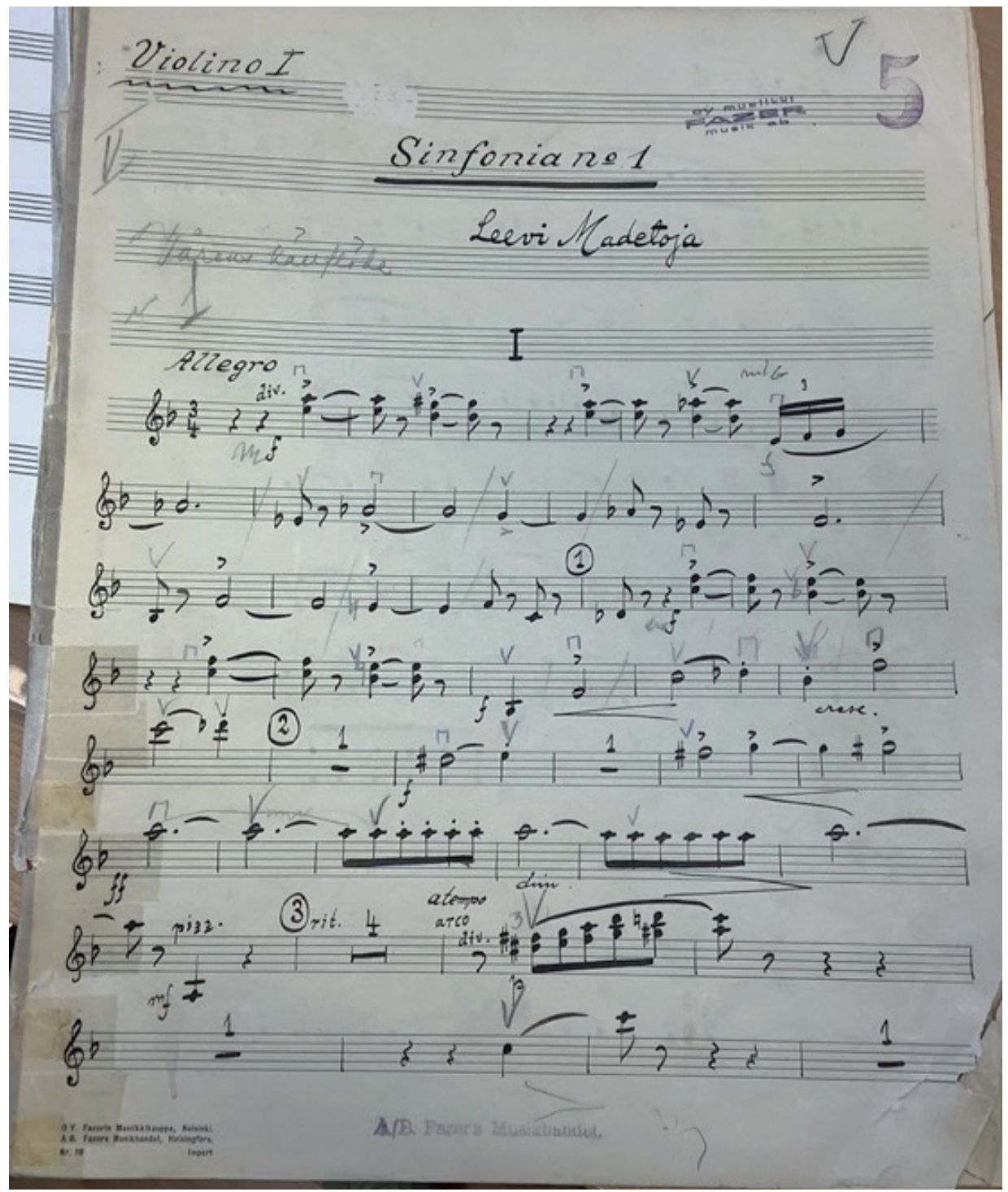

Kuva 12. "Vårens källflöde" - Fazerin orkesterimateriaalin 1. viulun äänilehti PB vl1 ${ }_{5}$.

tä on ympyröity vaaleanpunaisella.

Lähde PC sisältää sinfonian toisen osan "Lento Misterioso" käsinkirjoitetut orkesteriäänet. $^{52}$ Orkesterimateriaalia on säilynyt Kansalliskirjastossa 30 äänilehteä. ${ }^{53}$ Täydestä instrumentaatiosta puuttuu ainoastaan bassoklarinetin ääni-

52 Nämä orkesteriäänet ovat oletettavasti olleet säveltäjän omistuksessa, kunnes ne ovat siirtyneet Suomen Säveltäjien haltuun, ehkä testamenttilahjoituksena. Suomen Säveltäjät on lahjoittanut ne edelleen Kansalliskirjastoon. 53 Lisäkopioita on säilynyt tässä materiaalipaketissa vain kahdet 1. ja 2. viuluille, mutta ensiviulun toiseen 


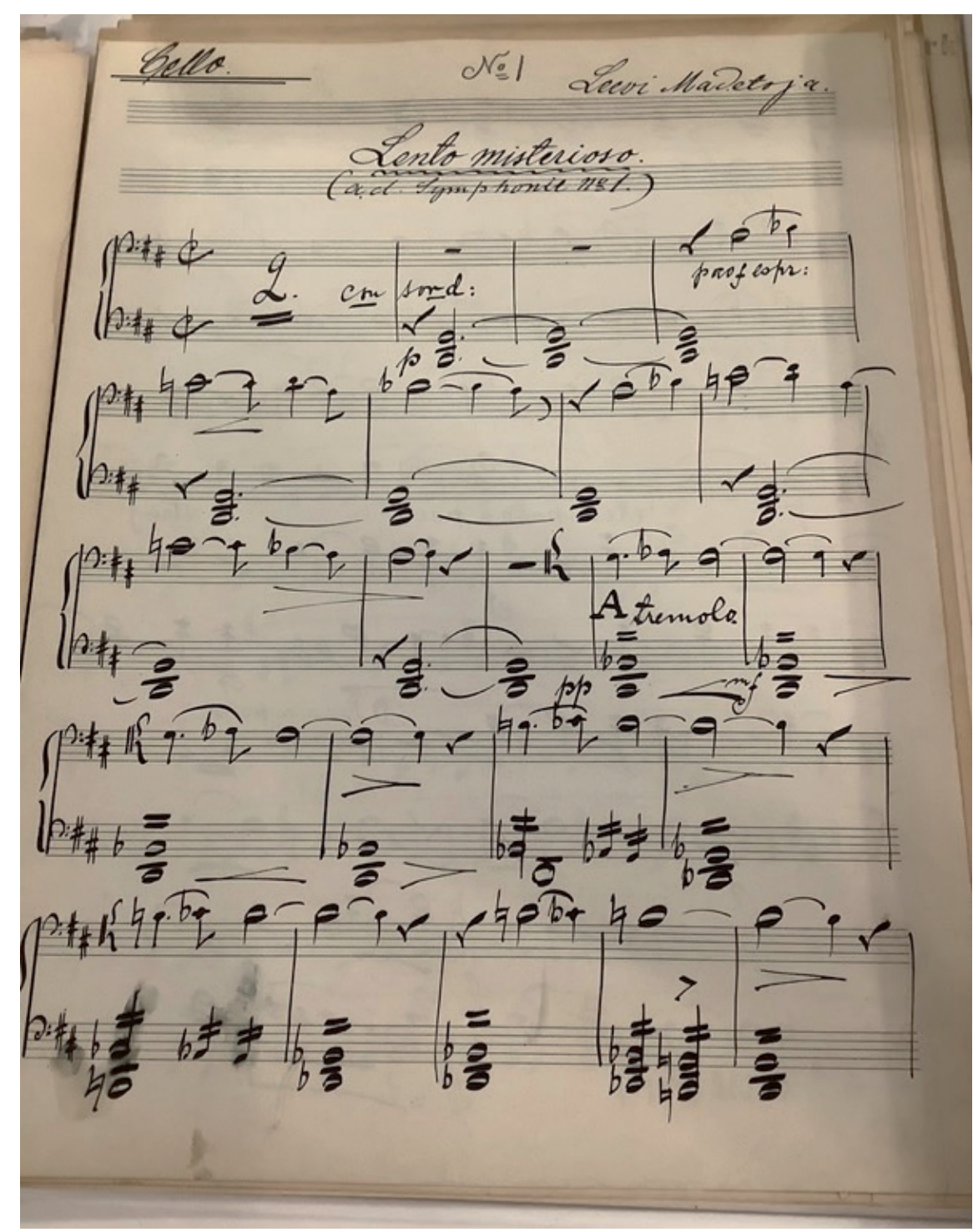

Kuva 13. "Lento misterioso". Sellon äänilehti orkesterimateriaalista PC. Kansalliskirjasto.

lehti. ${ }^{54}$ Äänilehdistä 26 on yhden kopistin käsialaa ja 4 toisen kopistin eri nuot-

lisäkopioon on kirjoitettu No. 6 ja toisen viulun toiseen lisäkopioon No. 5. Tästä voi päätellä, että lisäkopioita on ollut tarpeeksi paljon sen kokoiselle orkesterille, jossa on saattanut olla jopa 12 ensiviulua ja 10 toista viulua (koko jousiston mittasuhteet saattaisivat olla tällöin 12-10-8-6-4, mikä puhaltimien ja muiden soittimien kanssa yhdessä tarkoittaisi yli 60 hengen orkesterikokoonpanoa).

54 Äänilehti on saattanut kadota, mutta on myös mahdollista, että orkesterimateriaali on kopioitu sellaista orkesteria tai konserttitilaisuutta varten, jossa bassoklarinettia ei ole ollut saatavilla. Bassoklarinetti oli 1900-luvun alun Suomessa erittäin harvinainen soitin. 
tipaperilaadulle piirtämiä. Harjoituskirjaimet ovat A-partituurin mukaiset. Toisen oboen äänilehdessä on englannintorvisoolon alla lyijykynällä kirjoitetut soivat korkeudet, eli ainakin yksi esitys on saatettu soittaa ilman englannintorvea. Muiden puhaltimien äänilehdissä on myös lyijykynämerkintöjä, eli niitä on käytetty esityksessä, todennäköisesti säveltäjän johdolla. ${ }^{55}$

Yhdestäkään PC-äänilehdestä ei löydy niitä lyhennyksiä, jotka on tehty partituureihin $\mathrm{A}$ ja C ja myöskin äänilehtiin PA. On mahdotonta kiistatta todistaa, että nämä äänilehdet kuuluvat partituurin $\mathrm{C}$ yhteyteen, mutta se on varsin todennäköistä. Niitä on saatettu käyttää esimerkiksi Viipurissa tai Madetojan muiden orkesterivierailujen yhteydessä. ${ }^{56}$ Huomionarvoista on myös, että PC:n sellon äänilehdestä ei löydy minkäänlaista merkintää soolosta, vaan nuottikuva olettaisi ensimmäisen teeman olevan normaali divisi kahteen (kuva 13).

PC-orkesteriääniä ei ole kopioitu materiaalista $\mathrm{PA}$ eikä partituurista $\mathrm{C}$, vaan ne on kopioitu suoraan A-partituurista. Tämä näkyy muun muassa siinä, että isorummun äänilehdessä on sama erikoisuus kuin A-partituurissakin; sen ensimmäiset nuotit on kirjoitettu nuottiviivaston ylimpään väliin, ja seuraava sisääntulo on kirjoitettu toiseksi ylimpään väliin. C-partituurissa isorumpu on kirjoitettu kauttaaltaan keskimmäiselle viivalle. Madetoja on siis antanut orkesteriäänet piirtäneen kopistin käyttöön A-partituurin (tai A:n toisen osan irrallisen nuottivihkon ennen kuin partituuri on sidottu kansiin), ja hän on itse kopioinut $\mathrm{C}$-partituurin eri ajankohtana. ${ }^{57}$ Lähdeketjussa sekä $\mathrm{C}$ että $\mathrm{PC}$ siis polveutuvat $\mathrm{A}$ :sta. Tämä ei kuitenkaan vähennä sen todennäköisyyttä, että erillisen toisen osan partituuria ja orkesteriääniä on luultavasti käytetty yhdessä, semminkin kun molemmat ovat olleet säveltäjän itsensä hallussa.

Kuvassa 14 on kaikki partituurikäsikirjoitukset ja orkesteriäänet käsittävä lähdepuu, josta ilmenee, että alkuperäinen partituurikäsikirjoitus A on ollut partituurien B ja C lähteenä ja lisäksi siitä on kopioitu orkesterimateriaalit PA ja PC. Orkesterimateriaali $\mathrm{PB}$ on puolestaan tehty partituurin $\mathrm{B}$ pohjalta, vaikkakin kopioinnissa on todennäköisesti käytetty apuna HKO:n materiaalin äänilehtiä (PA), joissa monet säveltäjän tekemät muutokset ovat jo näkyvissä.

Madetojan ensimmäisen sinfonian vuonna 1984 Fazerin toimesta painatetun partituurin $(\mathrm{F})$ tausta on vielä selvittämättä, ja valitettavasti moni yksityiskohta jääneekin hämärän peittoon. Motiivia partituurin julkaisemiseen 1980-luvulla ei tarvitse etsiä kaukaa. Olihan näköpiirissä jo vuosi 1987 ja Madetojan syntymän

55 Näkemykseni on, että äänilehdet PC on tehty nimenomaan partituurin C kanssa käytettäväksi ja Madetojan omia konsertteja varten. Se tosiseikka on meiltä nykypäivänä unohtunut, että Madetoja oli varsin aktiivinen kapellimestari 1910-luvulla ja Helsingin töidensä lisäksi kiersi maamme muissa orkestereissa esittämässä omia teoksiaan.

56 Ajan esityskäytäntöön kuului, että sinfonioiden osia saatettiin soittaa irrallaan muusta teoksesta.

57 Äänilehtien PC ja PA vertailu puhuu myös sen puolesta, että PC on kopioitu partituurista A eikä äänilehdistä PA. 


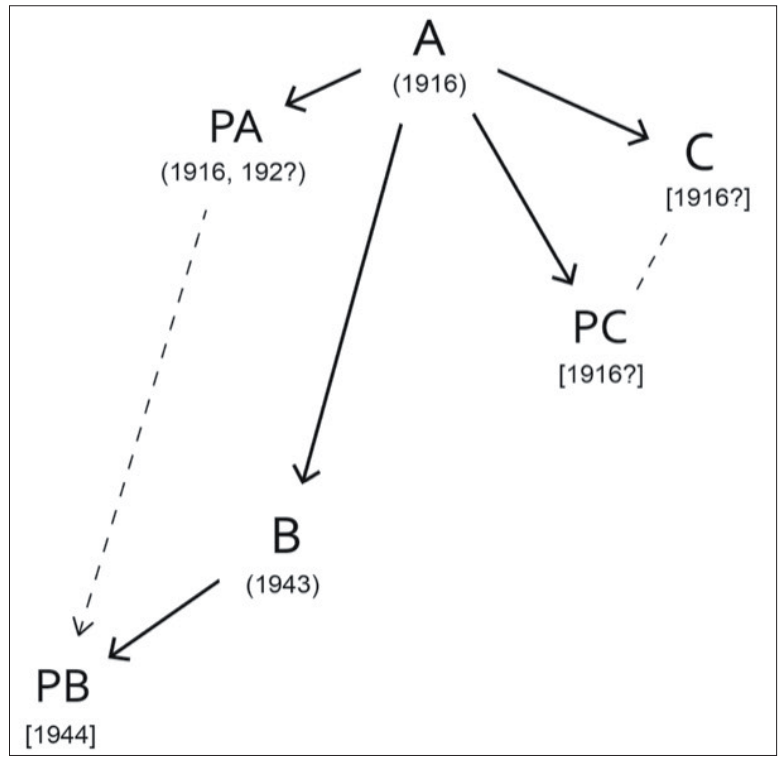

Kuva 14. Partituurikäsikirjoitusten ja orkesterimateriaalien lähdepuu.

100-vuotisjuhlat, jolloin orkesterit varmasti haluaisivat soittaa säveltäjän teoksia. Madetojan kolmas sinfoniakin tuli painosta juuri sopivasti vuonna $1987 .{ }^{58}$ Kun motiivi on ollut kaupallinen ja aikataulu tiukka, ei ole ihme, että partituuriin on pujahtanut monenlaisia virheitä. Valitettavasti Fennica Gehrman ei ole säilyttänyt ensimmäisen sinfonian toimitusprosessiin liittyvää kirjeenvaihtoa, joten painetun partituurin editori ei ole selvillä. Kolmannen sinfonian kohdalla tiedetään Madetojan sävellysoppilaan Olavi Pesosen olleen mukana toimitustyössä, joten on hyvin mahdollista, että Pesonen on vastannut myös ensimmäisen sinfonian editoinnista.

\section{JoHTOPÄÄTÖKSET}

Vuoden 1984 partituurin editorin käyttämien lähteiden dokumentoimattoman sekoittumisen (kontaminaatio) vuoksi partituuri F ei täytä modernin kriittisen edition vaatimuksia, joten uuden edition laatiminen teoksesta olisi tarpeellista. ${ }^{59}$ Edition voisi tietenkin yrittää perustaa kokonaan B-lähteeseen, mutta sen ollessa monilta osin puutteellinen on jo F:n 1980-luvun editori joutunut turvautumaan A:han ja yhdis-

58 Madetojan sinfonioiden julkaisuprojektin lienee pannut alulle Musiikki-Fazerin taiteellisena johtajana vuosina 1982-1984 toiminut Ilkka Kuusisto.

59 Kriittiseen editioon kuuluu olennaisesti käytettyjen lähteiden ilmoittaminen ja yhden niistä valitseminen päälähteeksi, minkä lisäksi kaikki tästä päälähteestä poikkeavat toimitukselliset ratkaisut perustellaan läpinäkyvästi kommentaarissa (Eskola 2019,13-14). Vuoden 1984 partituuri ei täytä näitä vaatimuksia miltään osin - minkäänlaista mainintaa lähteistä ei ole, kommentaarista puhumattakaan. Tämä on toisaalta ymmärrettävää, sillä Suomessa kriittinen editio on varsin uusi käsite - esimerkiksi Jean Sibeliuksen teosten kriittisten editioiden julkaisuprojekti (JSW) on aloitettu vasta vuonna 1996. 
telemään lähteitä. Yksi selkeimpiä esimerkkejä lähteiden epäonnistuneesta yhdistelystä on nähtävissä sinfonian toisen osan tahdeissa 78-87, missä säveltäjä on uusinut jakson dynamiikkaa, mutta merkinnyt sen puutteellisesti vuoden 1943 partituuriin. Tästä seurauksena painetussa partituurissa on eri soitinryhmillä epäjohdonmukaisesti eri dynamiikat (liite 1: https://trio.journal.fi/article/view/110033/64676).

Vuonna 2002 Fennica Gehrmanin toimesta teetetyt uudet orkesteriäänet $(\mathrm{PF})$ eivät parantaneet tilannetta, vaan itse asiassa huononsivat sitä. Tätä ennen orkesterit käyttivät vuoden 1943 partituuriin perustuvaa käsin kirjoitettua materiaalia (PB), vaikka kapellimestari olisikin käyttänyt vuoden 1984 partituuria (F). Orkesterimateriaalit siis välittivät kuulijalle "oikeamman" tekstin kuin painettu partituuri ${ }^{60}{ }^{6 u o-}$ den 2002 orkesteriäänet kuitenkin tehtiin vuoden 1984 partituurin pohjalta, jolloin niihin kopioitiin partituurin virheet ja epäjohdonmukaisuudet. Hyvä esimerkki tästä on ensiviulujen tahti 37 teoksen ensimmäisessä osassa, jossa lähteissä $\mathrm{A}, \mathrm{PA}$ ja $\mathrm{PB}$ on aladivisillä sävel dis, mutta partituurista $B$ on ylennysmerkki unohtunut pois. Tämä virhe on kopioitu painettuun partituuriin $\mathrm{F}$ ja se on sitä kautta päätynyt orkesterimateriaaliin PF, jota ei ole oikoluettu vanhaan, käsin kirjoitettuun materiaaliin vertaamalla (liite 2: https://trio.journal.fi/article/view/110033/64677). Kuvassa 15 on nähtävissä, mihin vuoden 1984 partituuri $(F)$ ja vuoden 2002 orkesteriäänet (PF) sijoittuvat lähdeketjussa.

Leevi Madetoja oli viisikymmentä vuotta täytettyään yhä enemmän huolissaan terveydestään ja kärsi monenlaisista epämääräisistä oireista. Hermojaan ja unettomuuttaan hän lääkitsi unilääkkeillä ja alkoholilla, ja sekakäyttö johti muiden ongelmien ohella muistin huononemiseen (Isohanni, M. \& Isohanni, I. 2001, 1389; ks. myös Mäkilä 2021). Säveltäjän heikon terveydentilan vuonna 1943 ja ensiesityksestä kuluneen ajan (27 vuotta) huomioon ottaen on vaikea nähdä, että B olisi varsinainen revisio. Se on akuutista tarpeesta (kustannussopimus) syntynyt kopio, joka näennäisestä selkeydestään huolimatta sisältää vakavia puutteita. ${ }^{61}$ Siksi A on sopivin päälähde uudelle kriittiselle editiolle. Kriittisen edition tulisi ottaa huomioon myös C, koska se on vähiten korruptoitunut partituuri sinfonian toisesta osasta alkuperäismuodossaan. Kriittisen kommentaarin voisi rakentaa siten, että sen perusteella olisi mahdollista konstruoida myös B-partituuria seuraileva tulkinta, joka olisi yhtenäisempi ja vakuuttavampi kuin vuoden 1984 julkaisu (F). Toinen vaihtoehto olisi julkaista kriittiset editiot sekä vuoden 1916 kantaesitysversiosta että vuoden 1943 versiosta, joskin jälkimmäinen vaatisi melko voimakasta toimitustyötä säveltäjän il-

60 Mielestäni kriittisen edition toimittamisen tulisikin pitää sisällään myös orkesterimateriaalien huolellinen toimittaminen. Soiva lopputulos perustuu viime kädessä kuitenkin soittajan edessä olevaan nuottitekstiin, ei kapellimestarin edessä olevaan partituuriin.

61 Madetoja kirjoittaa päiväkirjassaan 23.8.1943: "I sinfonia on saatava kaupatuksi että saa vapaita käyttövaroja." Hän oli sota-aikana ymmärrettävästi huolissaan rahavarojensa riittävyydestä. Säveltäjän käsitystä omasta työkyvystään puolestaan kuvaa hänen päiväkirjamerkintänsä 12.9.1943: ”à 14:30 oli Ork. konsertti, jonka ohjelmassa oli ‘Tanssinäky'. Sitä, ja koko ohjelmaa kuunnellessani totesin jälleen: Kuuloaistissani ja siihen liittyvässäälyntoiminnassani on jotain vikaa. Minun täytyy työssäni keskittyä valmiiden teosteni julkaisemiseen. Siinä täytyy saada joku avukseni!” 


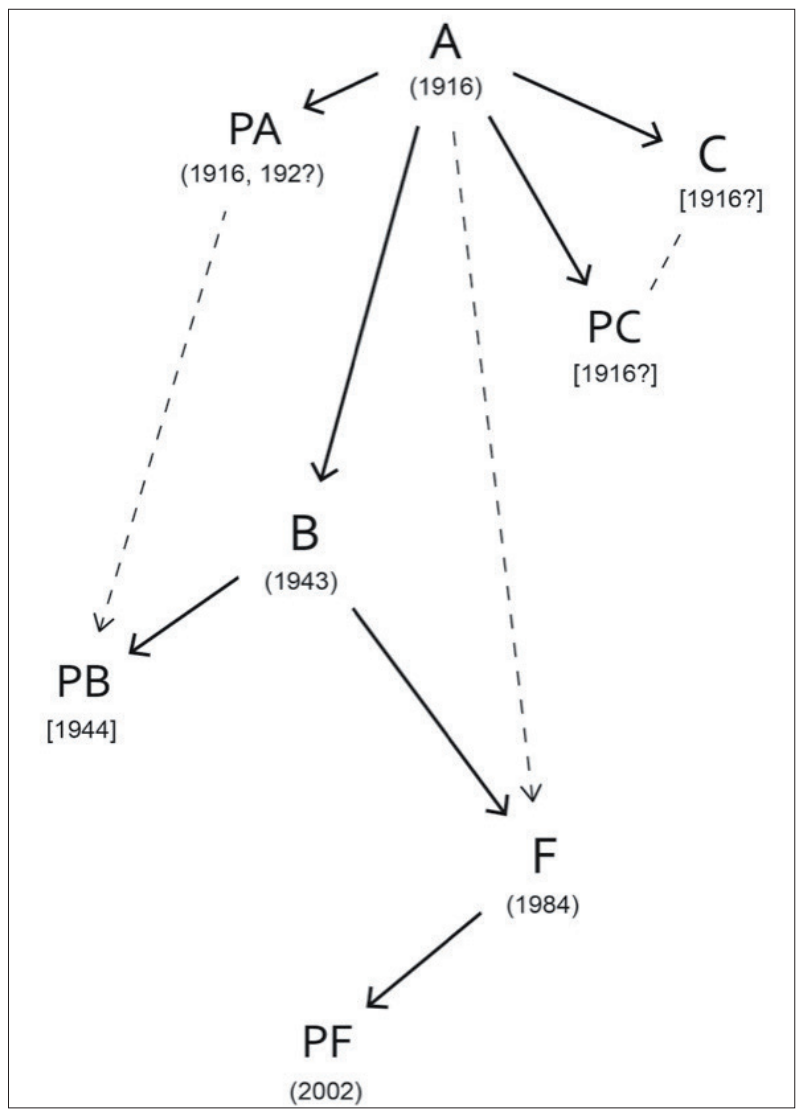

Kuva 15. Painetun partituurin (F) ja modernien äänilehtien (PF) sijoittuminen lähdeketjuun.

meisten unohdusten ja virheiden oikaisemiseksi.

Jatkotutkimusta tämän sinfonian parissa voisi ajatella etenkin sinfonian versiohistorian kannalta - eri kopisteilta peräisin olevien äänilehtien tarkempi ajoittaminen saattaisi tuoda lisävalaistusta siihen, milloin mikäkin muutos on tehty. Myös orkesteriäänissä olevat merkinnät esityspäivämääristä täydentävät osaltaan teoksen esityshistoriaa. Tutkimusta voisi tehdä myös partituurissa olevista kapellimestarien merkinnöistä. Madetojan, Kajanuksen ja esimerkiksi Schnéevoigtin yksityisessä käytössä olleita partituureja tutkimalla saattaisi olla mahdollista erottaa eri merkintöjen tekijät toisistaan ja näin varmistua siitä, mitkä merkinnöistä edustavat säveltäjän itsensä näkemystä, mitkä muiden esittäjien. Myös Madetojan muu orkesterituotanto on tutkimuksen kannalta vielä varsin neitseellistä maaperää: toinen ja kolmas sinfonia odottavat omia kriittisiä editioitaan, oopperoista puhumattakaan. Säveltäjän henkilökuvaakin olisi mahdollista vielä huomattavasti tarkentaa tämän kirjeenvaihdon ja päiväkirjojen perusteella. 


\section{LÄHTEET}

Käsikirjoitukset ovat luettavissa artikkelin liitteissä:

Liite 1. https://trio.journal.fi/article/view/110033/64676

Liite 2. https://trio.journal.fi/article/view/110033/64677

NuоtтікёSIKIRJoitukset:

Madetoja, Leevi. Sinfonia No.1. Säveltäjän alkuperäinen käsikirjoitus, 1916. Ms.Mus.163 Madetoja 4/4. Kansalliskirjasto.

Madetoja, Leevi. Sinfonia No.1. Säveltäjän käsikirjoituskopio, päiväämätön [1943]. Ms.Mus.163 Madetoja 4/4. Kansalliskirjasto.

Madetoja, Leevi. Sinfonia No. 1. II. Lento misterioso. Säveltäjän käsikirjoituskopio sinfonian toisesta osasta, päiväämätön [1916?]. Ms.Mus.Mt1. Kansalliskirjasto.

Madetoja, Leevi. Sinfonia. Helsingin kaupunginorkesterin käsin kirjoitetut orkesteriäänet [1916, 192?]. Ue:94 nuottimateriaali 530. Helsingin kaupunginarkisto.

Madetoja, Leevi. Sinfonia. Käsin kirjoitetut orkesteriäänet [1916, 192?]. Ms.Mus.Suomen Säveltäjät 8. Kansalliskirjasto.

Madetoja, Leevi. Sinfonia No.1. Fazerin käsin kirjoitetut orkesteriäänet [1944]. Ei signumia. Fennica Gehrman, Helsinki.

Madetoja, Leevi. Lento misterioso. (a.d. Symphonie no. 1.). Sinfonian toisen osan käsin kirjoitetut orkesteriäänet [1916?]. Ms.Mus.Suomen Säveltäjät 8. Kansalliskirjasto.

PAINETUT NUOTIT:

Madetoja, Leevi 1984. Symphony No. 1. Orkesteripartituuri. Helsinki: Fazer.

Madetoja, Leevi 2002. Symphony No. 1. Orkesterin äänilehdet. Helsinki: Fennica Gehrman.

Madetoja, Leevi 2020 (toim. Tuomas Niemelä). Mieskuorolaulut-Works for Male Choir a cappella. Helsinki: Ylioppilaskunnan Laulajat.

MuU KÄSIKIRJOITUSMATERIAALI:

Leevi Madetojan kirje Eero Kososelle 29.12.1932. 9.30 Kosonen, Eero 4.1.9:2. Tampereen kaupunginarkisto.

Arvo Räikkösen kirje Leevi Madetojalle 23.9.1933. Coll. 276. Kansalliskirjasto.

Leevi Madetojan päiväkirja [1943]. Coll. 276.5. Kansalliskirjasto.

SÄHкÖISET LÄHTEET:

Helsingin kaupunginorkesteri 2020. Helsingin kaupunginorkesterin konsertit 1882-. 11.5.2020. https://hri.fi/data/dataset//helsingin-kaupunginorkesterin-konsertit.

KirJallisuus:

Bonsdorff, Lena von 2012. Roger Lindberg: mentori, mesenaatti, musiikkikauppias. [Mentor, mecenat, musikhandlare: Invandrarättlingen Roger Lindberg blir Mr Music of Finland] Käsikirjoituksesta suomentanut Sirpa Hietanen. Helsinki: Schildts \& Söderströms.

Edge, Dexter 2001. Mozart's Viennese Copyists. Väitöskirja, University of Southern California.

Eskola, Jari 2019. Historiallisesti taustoitettu nuottieditio. Louis Spohrin Notturno op. 34 hermeneuttisena haasteena. Pro gradu -tutkielma, Helsingin yliopisto. http://urn.fi/URN:NBN:fi:hulib-202001291188

Feder, Georg 1987. Musikphilologie. Darmstadt: Wissenschaftliche Buchgesellschaft.

Grier, James 1996. The Critical Editing of Music: History, Method, and Practice. New York, NY: Cambridge University Press. 
Isohanni, M. \& Isohanni, I. 2001. Liittyvätkö lahjakkuus ja mielenterveyshäiriö toisiinsa? Suomen lääkärilehti 12/2001,1385-90.

Karjalainen, Kauko 1991. Leevi Madetojan oopperat Pohjalaisia ja Juha. Väitöskirja. Studia musicologica Universitatis Helsingiensis, 2. Helsinki: Helsingin yliopiston musiikkitieteen laitos.

Katila, Evert 1916. Sinfoni I av Leevi Madetoja. Analys av E. Katila. Tidning för musik, februari 1916, 25-28.

Kilpeläinen, Kari 1991. Tutkimuksia Jean Sibeliuksen käsikirjoituksista. Väitöskirja. Studia musicologica Universitatis Helsingiensis, 3. Helsinki: Helsingin yliopiston musiikkitieteen laitos.

Kuula, Pentti 2006. Viipurin Musiikin Ystävien orkesteri suomalaisen ja kansallisen identiteetin edistäjänä 1894-1918. Studia Musica 28. Helsinki: Sibelius-Akatemia. http://urn.fi/URN:ISBN:978-952-329-214-7

Makkonen, Anna \& Tuurna, Marja-Leena (toim.) 2006. Yölauluja: L. Onervan ja Leevi Madetojan kirjeitä 1910-1944. Helsinki: Suomalaisen Kirjallisuuden Seura.

Murtomäki, Veijo 1999. Sibelius-tutkimuksen nykytilaa. Tieteessä tapahtuu 17(1) [ei sivunumeroita]. https://journal.fi/tt/article/view/58305

Mäkilä, Sasha 2018. Conducting Madetoja. Discoveries About the Art and Profession of Conducting. Väitöskirja, Eesti Muusika- ja Teatriakadeemia. https://www.ema.edu.ee/vaitekirjad/doktor/Sasha_Makila.pdf

Mäkilä, Sasha 2020. Leevi Madetojan ensimmäinen sinfonia taiteellisen ja tieteellisen tutkimuksen risteyksessä. Musiikki 50 (3), 77-94. https://musiikki.journal.fi/article/view/98150

Mäkilä, Sasha 2021. "Jumalan avulla absolutistiksi!" Alkoholin vaikutus Leevi Madetojan luomiskykyyn vuoden 1943 päiväkirjamerkintöjen valossa. Synkooppi op. 142 (1/2021), 18-29. https://synkooppilehti.wordpress.com/2021/05/18/jumalan-avulla-absolutistiksi/

Niemelä, Tuomas 2017. Leevi Madetojan varhaisten mieskuorolaulujen julkaisuhistoria. Päälähteen märitteleminen uutta kriittistä editiota varten. Pro gradu -tutkielma, Helsingin yliopisto.

Piippo-Fair, Hannele 1990. Suomalaisen nuotinkirjoituksen vaiheita 1920-luvulta 1970-luvun taitteeseen. Kandidaatintutkielma, Sibelius-Akatemia.

Salmenhaara, Erkki 1987. Leevi Madetoja. Helsinki: Tammi. 